
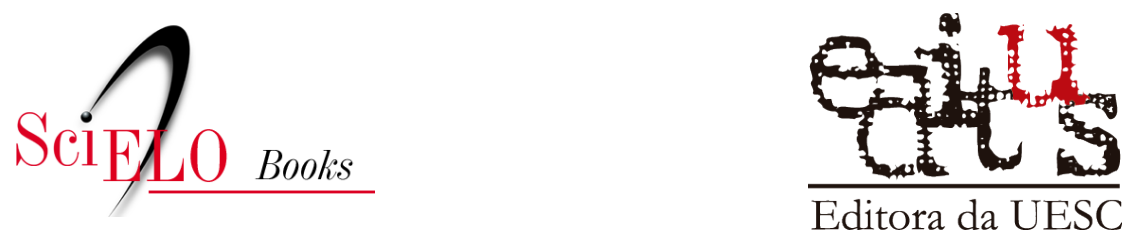

\title{
5 As/os quilombolas de Volta Miúda em perfil
}

\author{
Raíssa Félix
}

\section{SciELO Books / SciELO Livros / SciELO Libros}

FÉLIX, R. As/os quilombolas de Volta Miúda em perfil. In: Volta miúda: quilombo, memória e emancipação [online]. Ilhéus, BA: Editus, 2020, pp. 84-144. Transfluência series. ISBN: 978-6586213-14-0. https://doi.org/10.7476/9786586213317.0006.

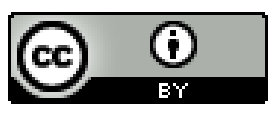

All the contents of this work, except where otherwise noted, is licensed under a Creative Commons Attribution 4.0 International license.

Todo o conteúdo deste trabalho, exceto quando houver ressalva, é publicado sob a licença Creative Commons Atribição 4.0.

Todo el contenido de esta obra, excepto donde se indique lo contrario, está bajo licencia de la licencia Creative Commons Reconocimento 4.0. 


\section{As/os quilombolas de Volta Miúda em perfil ${ }^{9}$}

\subsection{BRASÍLIA FIRMINA}

Bisneta de Vitória, neta de Flausina, filha de Firmina Flausina. Dona Brasília nasceu em Volta Miúda, em 1933, "pôco tempo" depois que a escravidão foi proibida no Brasil. As memórias que a constituem vêm de mãos dadas com o alerta: "A gente pensa que não acaba, mas acaba sim".

- E tem jeito de não acabar?

- Tem sim. É só um só num querê abraçá o mundo todo.

O lembrar revivifica-a. Dona Brasília se apresenta como a mulher rendeira, que viu a mata e as águas em abundância, nascida e criada numa Volta Miúda que, muito além dos sombrios tempos da escravidão, rendeu-lhe cantos, ritmos e fé. Ensinou-lhe liberdade.

A bisneta da "véia Vitória" vem de um tempo em que os mais velhos eram sinônimo de conhecimento e sabedoria. Já nos tempos de hoje as coisas estão se acabando porque há muito a se falar, mas os jovens não querem escutar. Naquela 
época, as crianças, curiosas, rodeavam as conversas, observavam de longe - "minino novo era inteligente" - tentavam aprender com quem já tinha vivido muito.

E foi assim, observando, que Dona Brasília se tornou a mulher que testemunhou tempestades serem acalmadas com canto e dança. Chovia muito, trovões e relâmpagos tomavam o céu quando a bisavó Vitória se vestiu para conversar com o tempo. Com um pano amarrado na cabeça, uma toalha branca, para sustentar uma bacia com pedra dentro.

Dona Brasília não entendia a língua, mas assistiu ao diálogo entre a "véia Vitória e a truvuada"... e se passava assim: mulher e tempo conversavam, ela lhe pedia que se afastasse e os trovões iam embora, ficavam mais longe, longe... até que não se ouvia mais nada.

Aquela língua permaneceu desconhecida para a criança Brasília, mas ela aprendeu com a "véia Vitória", uma ex-escrava, a conversar com a natureza, respeitá-la - aprendeu que, afinal, "Deus dexô o mundo muito grande, que dá pra tudo quanto há vivê".

Os olhos reflexivos da mulher que viu uma lagoa encantada falam sobre outro tempo. "Tudo assim existia, mas agora o século já mudô que a gente nem sabe o dia". A lagoa encantada ficava para o lado de Naiá, e não secava nunca. Lá, os 'embreves' davam significado à vida e à morte.

- O que que é embreve? - Dona Brasília se pergunta em voz alta, como quem revela uma informação secreta, dividida apenas entre amigos. Contando a história de uma velhinha doente, ela fala sobre a oração copiada dentro de 
uma bolsinha de pano - o embreve - que, jogada dentro do olho d'água, desceu, e lhe definiu a hora da morte. Ao saber que o embreve fora entregue, "aí se virô de costa e só espichô, foi embora, só fez entregá, morreu". Sem pesar, nem dor, a partida é relatada como resultado do cumprimento de uma tarefa, uma etapa. E, por que não, de um tempo.

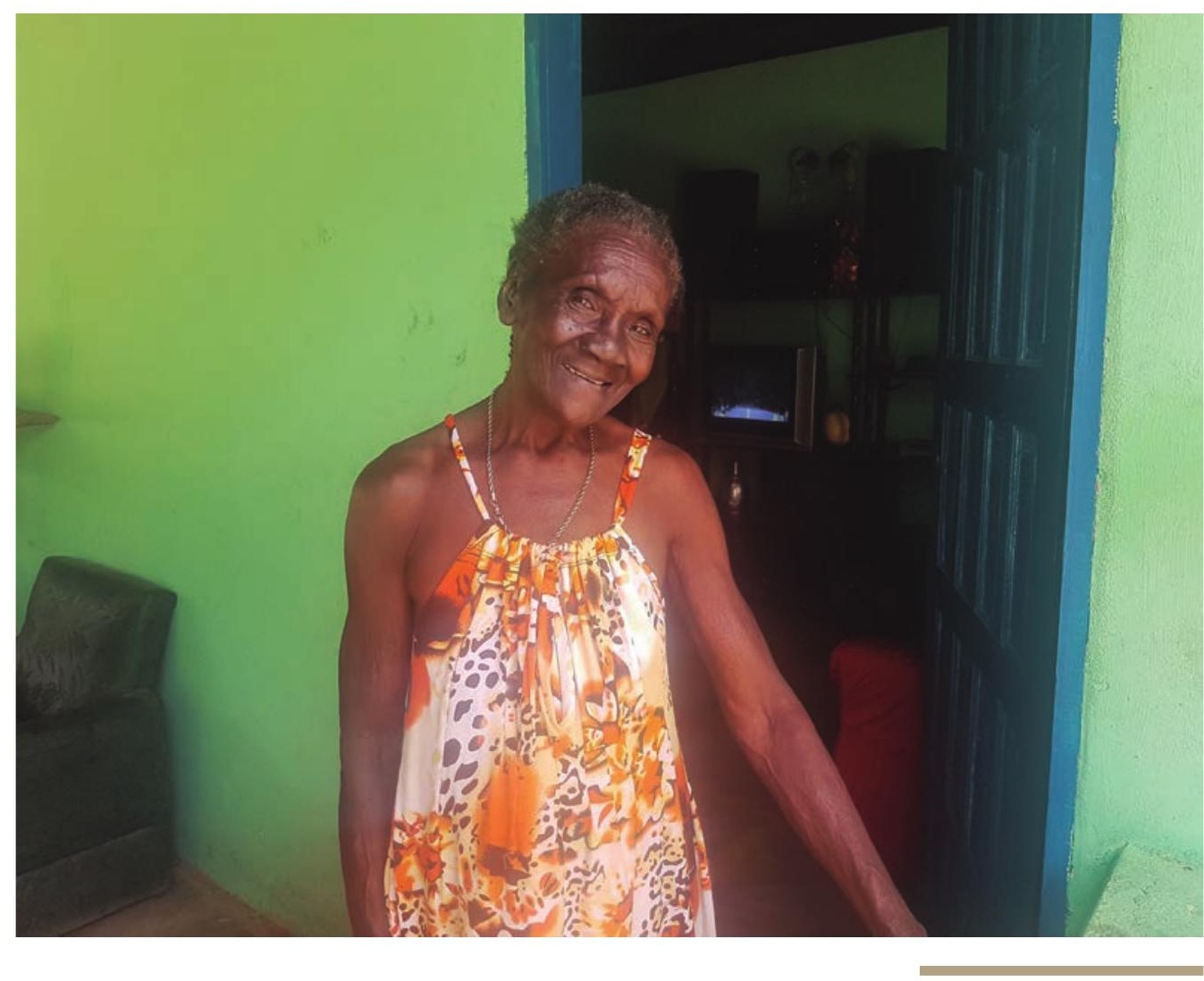

3 - Brasília Firmina (2019). 
A cena verbalizada com os olhos fixados no horizonte diz muito mais sobre a beleza do lugar, quase posso vê-la, mesmo agora. E como era linda a lagoa encantada. "Nunca secava, minha sinhora, quando ficava desse lado que olhava para o lado de lá os bichinho tava pequenininho". Enorme. Mas o século é outro, nem se sabe o dia, e, "Deus me perdoa, que não existe mais Mãe d'Água". Pesar.

A moça que levou o embreve contou para Dona Brasília: Mãe Xandinha que ensinou como salvar a menina que foi pegar água e sumiu. Para resolver o sumiço, Mãe Xandinha ordenou: "ocê, ocê, ocê... Ocês vai lá na beira da lagoa, cêis fica bateno palma e cantano". E a menina voltou toda moIhada, veio do olho d'água e nunca mais falou uma palavra - para não contar o que viu por lá.

A música vem à tona: cantavam os escravos, cantavam os homens que trabalhavam na mata, cantavam as mulheres amassando barro, torrando a farinha e cantando - "sofrendo tanto e ainda com alegria, ainda cantava". A musicalidade também é parte integrante desta bisneta da "véia Vitória", neta de Flausina e filha de Firmina Flausina. Se ela ainda canta? "A gente sofreu dimais, num era escravo, mas sofreu muito".

A lagoa que era encantada virou terra. E não existe água lá, imagina no rio. O lugar que Mãe d’Água entrava para sair na lagoa - que era tão lisinho e profundo o caminho acabou com a modernagem, mudando gente e capinando e plantando e o eucalipto puxando a água, e mudando gente e capinando e o eucalipto puxando a água. Sim, Dona Brasília ainda tem muitos motivos para cantar. 


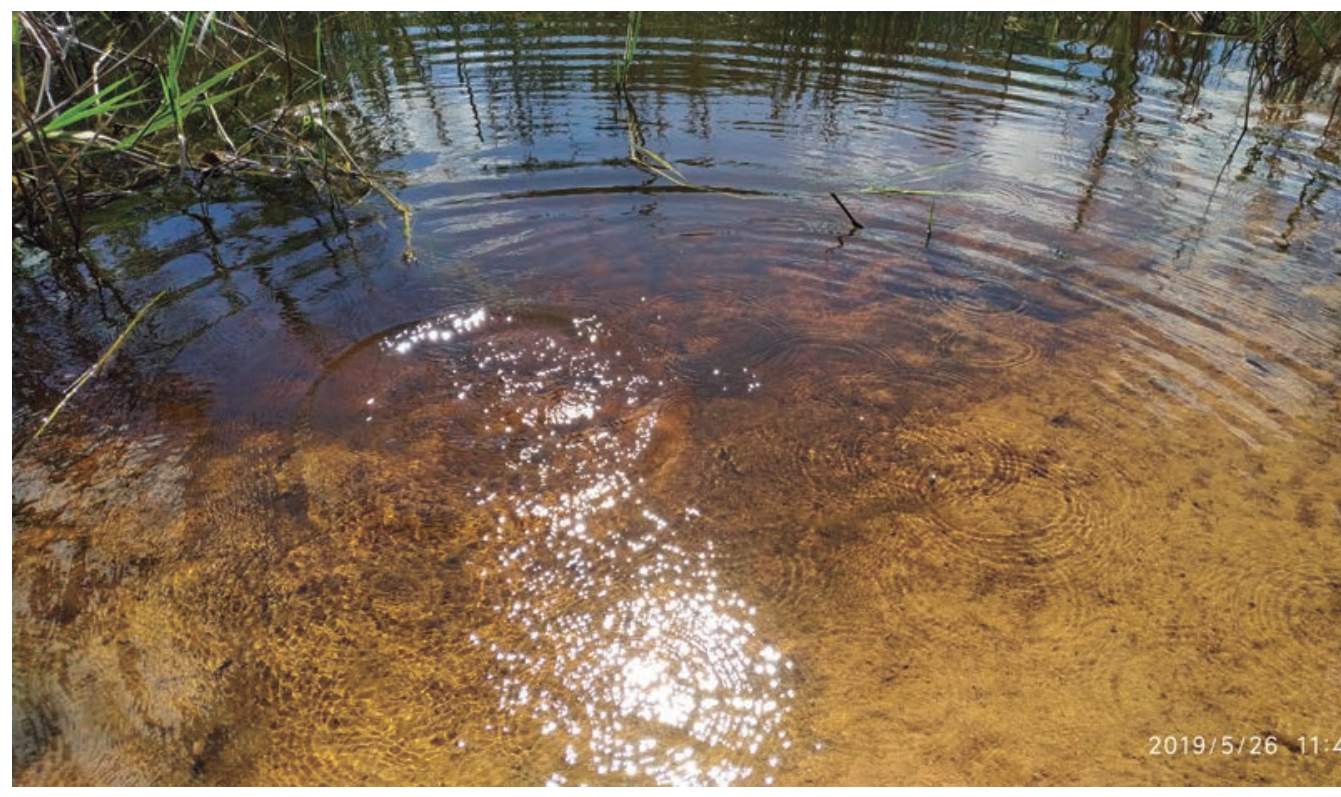

4 - llustração da

lagoa (2019). 


\subsection{MANOEL DE DELFINA}

O cantador do Ofício é filho de Delfina Joaquina Josefa e neto de Joaquina Josefa, nascida no dia em que foi declarada a liberdade aos escravizados, em 13 de maio de 1888. As bisavós e bisavôs de Seu Manoel foram libertados nesta data.

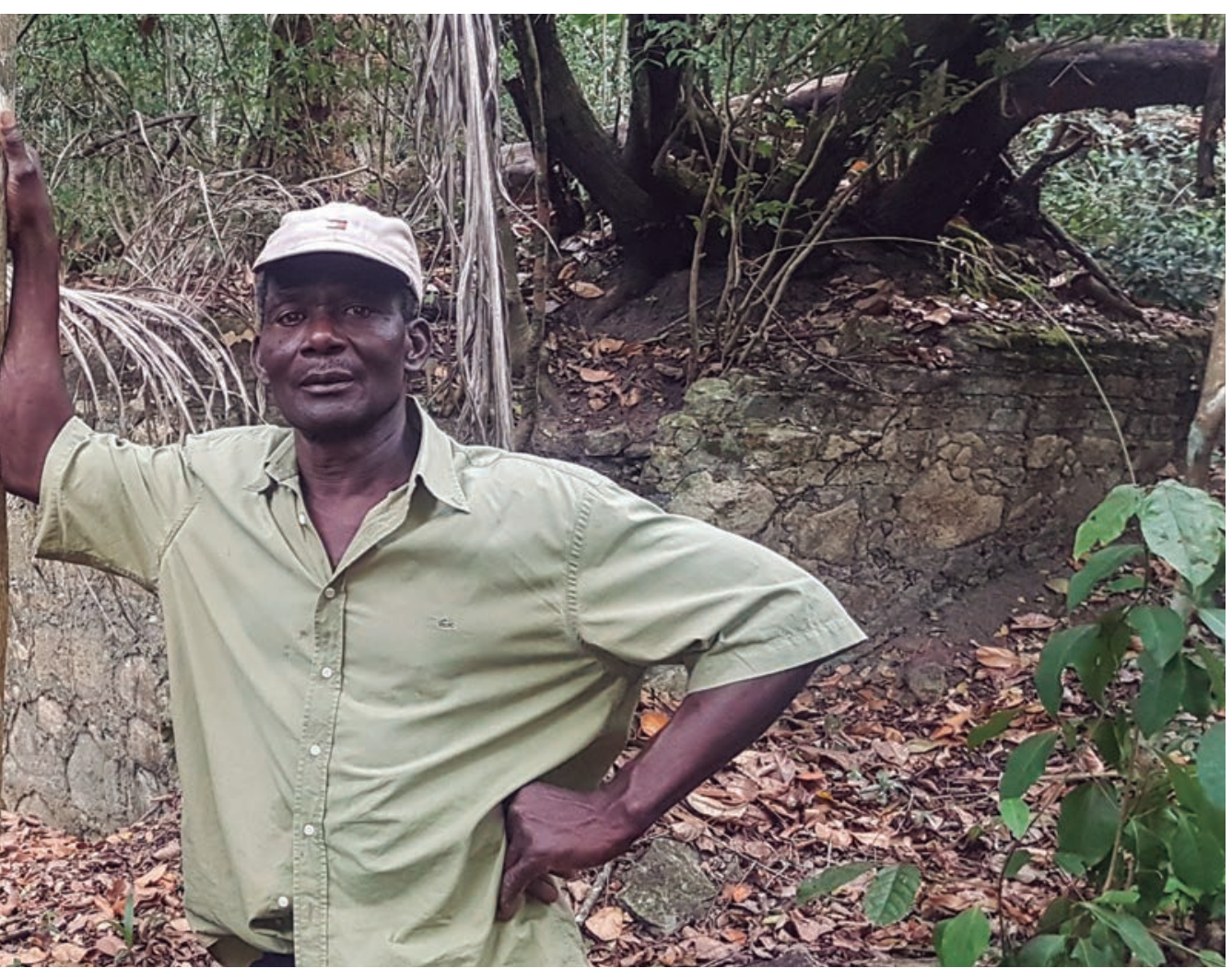

5 - Manoel de Delfina (2019). 
No dia em que visitou as ruínas da senzala, 130 anos depois daquele dia, refletiu: "isso aqui foi os escravo que fez". Arcos em pedra, um canal que desemboca no rio Peruípe, a escadaria em pedra que nos leva a um terreiro. Bases em pedra, em pé. Sob sangue e suor e força e resistência afinal de contas, ainda estamos aqui.

Que é ser livre? Reflito.

"Na cidade eu fico preso", Seu Manoel desafia os limites da própria liberdade.

"Cortano a conversa, eu sei cantá o Ofício". Sim, Seu Manoel Reis, que se apresenta como Manoel de Delfina - sua mãe -, é um mestre em cantar o Santo Ofício. Requisitado, se quiser tê-lo em um terço ou reza, há de verificar se já não foi convidado a outro lugar. Vão até ele, buscam-no para a realização desta sacralidade - desta arte - que aprendeu ainda jovem, sozinho.

Aprendeu de cor, ninguém ensinou. $O$ rezador adiante, e ele observava atento. Aprendeu. Pediu para Celestino a oportunidade para rezar, "não, assim não aprende não". Mas Seu Manoel aprendeu sem que Ihe ensinassem.

Um dia, depois de cantar folia de reis o dia inteirinho na Festa de São Sebastião, foi surpreendido: "é pra você vim cantá reza mais Cassimiro". Desse dia em diante não parou mais, Nanuque, Teixeira, Caravelas, "eu tenho saído pra cantá reza nesses canto tudo, aprendi sozinho".

A Folia de Reis aprendeu quando ia para a casa da sua avó Joaquina passar uns dias. Saía a Folia cantando com a caixa e o pandeiro, oito, dez, 12 foliões... juntos iam às casas 
convidando para as festas de santo. "Tem a festa de São João em Juerana, a festa de Santo Antônio em Caravelas, tinha a de Nossa Senhora da Piedade em Helvécia, de São Benedito em Nova Viçosa".

Homens, com caixa e pandeiro, cantando e brincando faziam a sua religião. Religavam-se a Deus recebidos por seus pares, em comunidade, em oração e em comunhão.

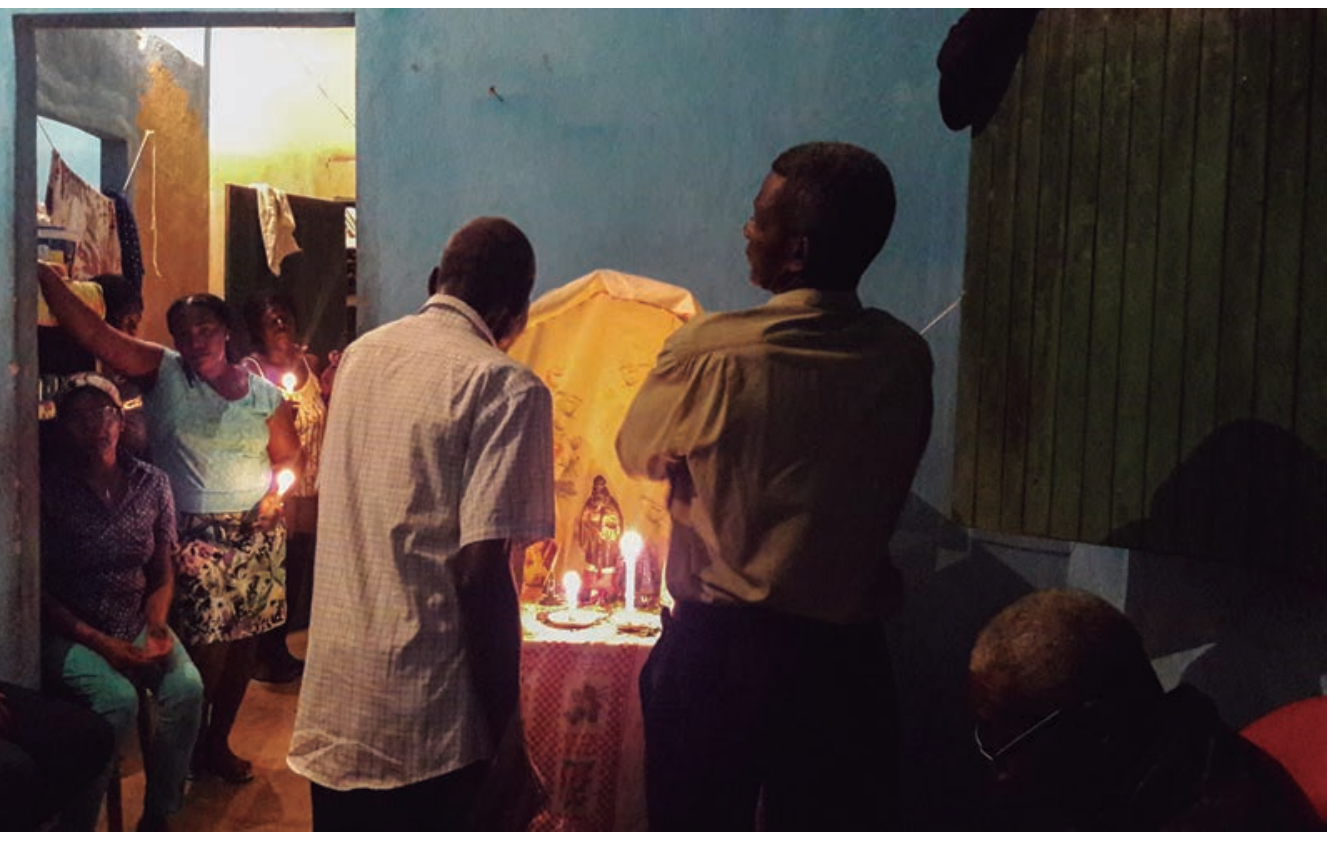

6 - Manoel de Delfina rezando $O$ Santo Ofício (2018). 

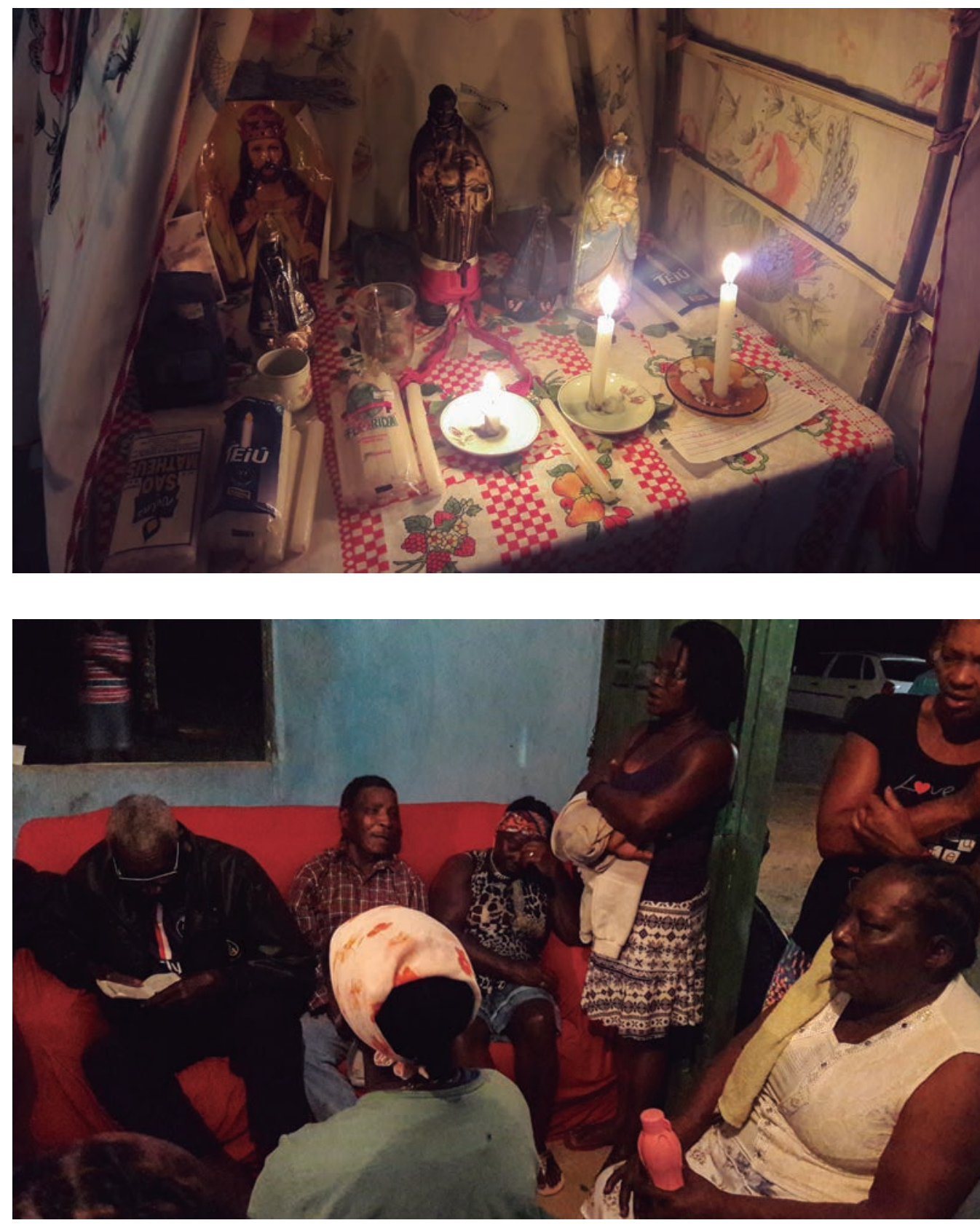

7 - Altar, reza do

Santo Ofício (2018).

8 - Comunidade, reza do Santo Ofício

(2018) 


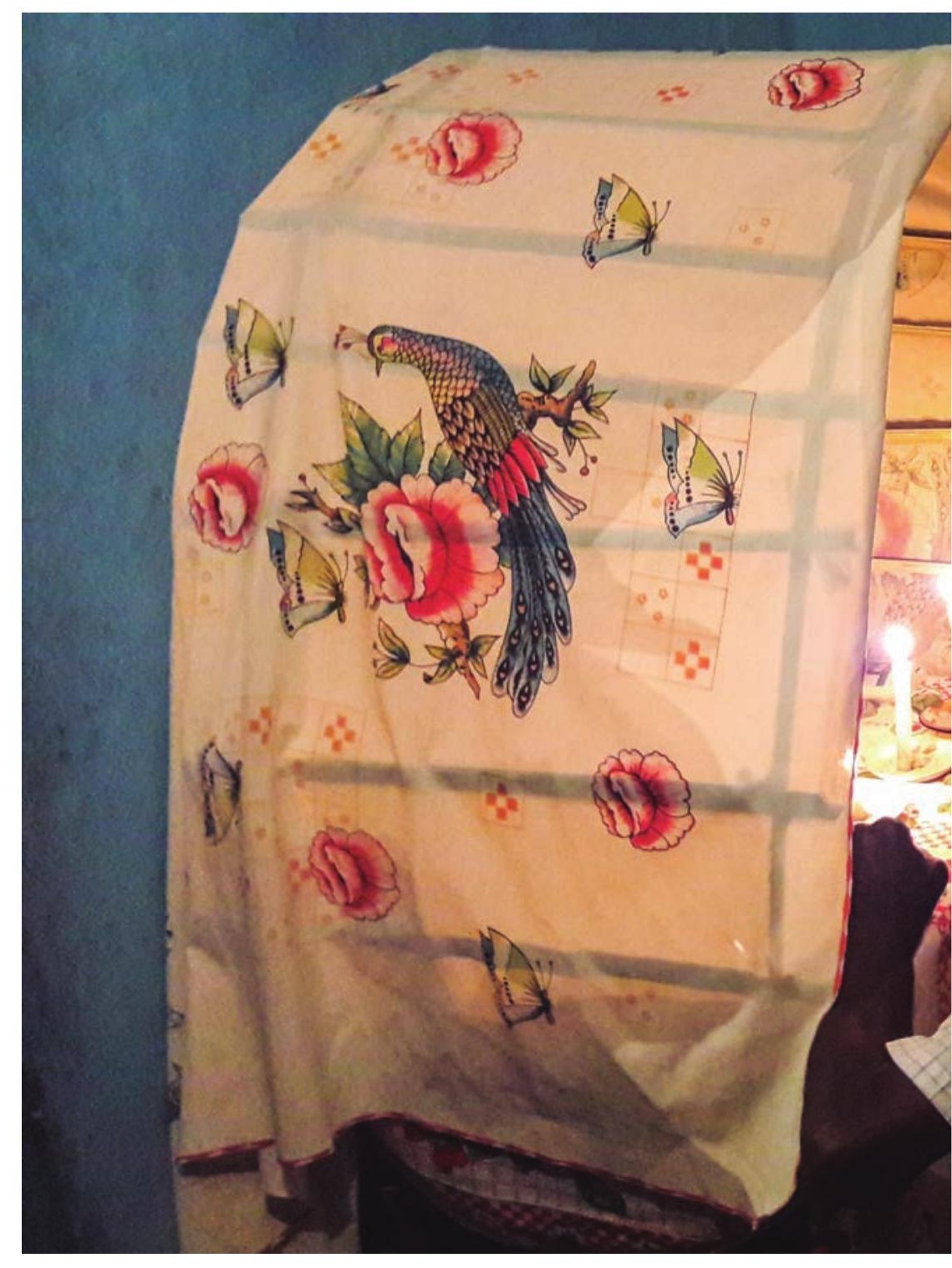

92 


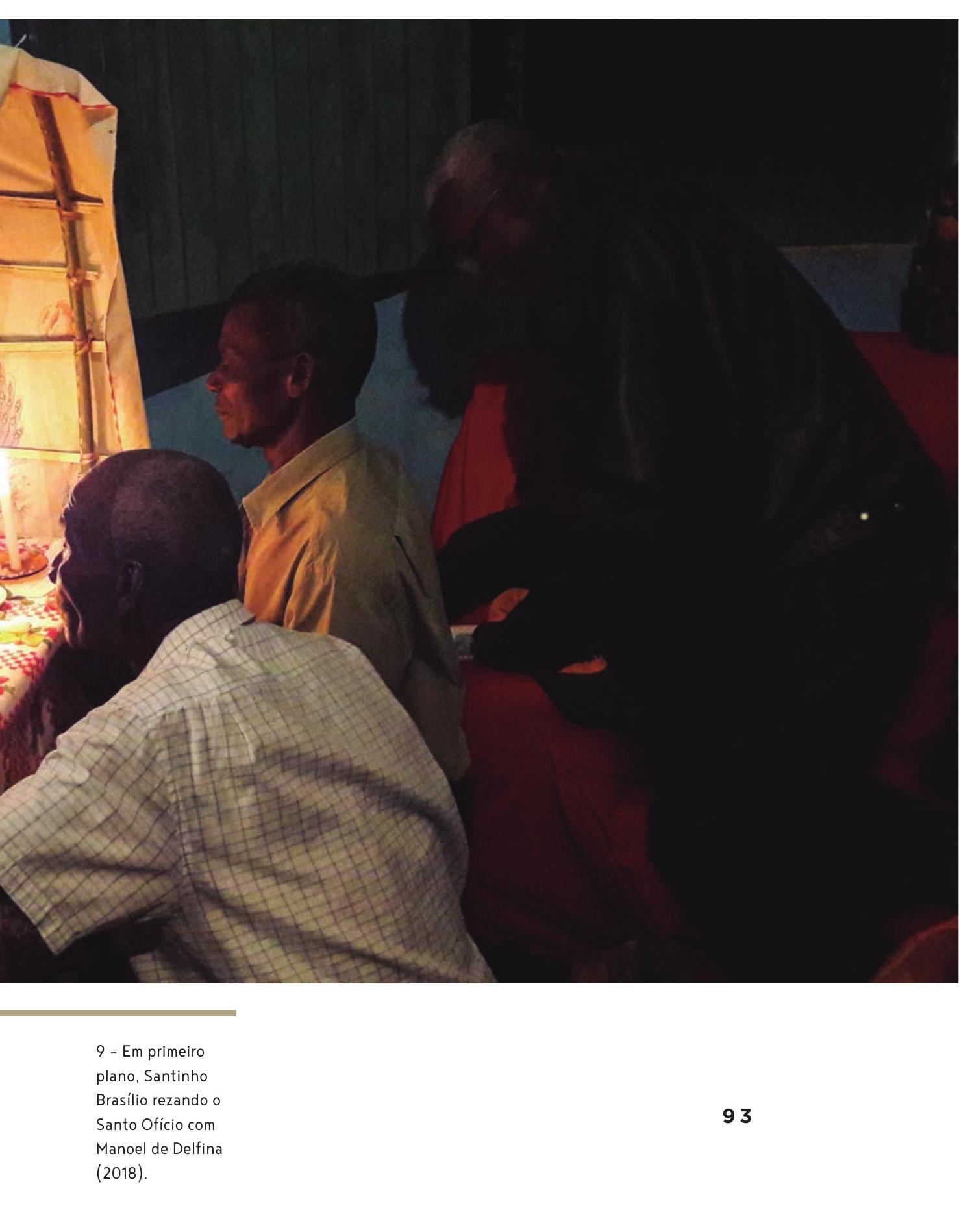


Seu Manoel é um homem de fé. Dona Delfina, sua mãe, viveu graças a ele. Quando pouco mais nova, adoeceu. Não comia, não bebia, não falava. Levaram-na ao hospital em Helvécia, depois ao Santa Rita em Teixeira de Freitas. E os médicos insistiam: se não internar, ela piora. Para Manoel, de tão ruim a situação, a piora ia levá-la à morte. E não parecia certo deixá-la se acabar em hospital.

Em casa, "assim de gente oh, cheia!", achou melhor falar com os irmãos Casimiro e Joaquim para deixar animal preso, preparar-se para dar a notícia. Mas, o destino outrora definido, agora podia ser outro - afinal, há muito tempo eram donos da liberdade, com a bênção de Deus.

Mês de maio, fazia frio, eram 3 horas da manhã quando Seu Manoel se levantou da mesa - "tem coisa que é Deus que bota na cabeça da gente". "Maria", disse à irmã, "eu vôlá na casa daquela muié rezadeira”. E foi, afinal, "Deus que envia a gente".

O nome da rezadeira era Maria de Florência - chamada até de Maria Macumbeira. "O sinhô aqui é nuvidade muito grande, num é?", disse ela. Era mesmo. "Purque eu tô com minha mãe lá tantos dias, já fui no médico e tal", o dia já estava amanhecendo quando a rezadeira tomou a decisão: "me chamou e disse: faz isso, e isso, compra óleo de amêndoa, óleo de rizo, a folhinha de poejo, alevante, o que era pra fazê, eu fui fazeno".

Manoel de Delfina chegou em casa ao meio-dia com a reza pronta, explicou conforme Maria de Florência mandou fazer. E, depois de mais de 15 dias sem conversar, só pela mão dos outros, Delfina soltou a fala, estava com fome. E sarou, seguiu os remédios e viveu. Morreu com 95 anos. Seu Manoel é um homem de fé. 
"Com respeito a quarquer um", mas também com o humor - afinal "se a gente não fizé graça morre à toa, viu?".

A ausência da visão não afeta a sua capacidade de ver - sentir - o mundo.

Domingos Serafim não enxerga "desde os tempo do URV". Começou a "senti das vista" no início da década de 1990, foi a vários médicos, mas nenhum deles conseguiu curá-lo. Ele conta e não lamenta: "Tô conformado com Deus, é, parado eu também num fiquei não, lutei muito". As transformações do mundo à sua volta são sentidas em outras dimensões, e permanece vivaz o cenário da Volta Miúda do século passado.

Pai de oito filhos, está "no poder de tataraneto", casou-se com Tereza Paulo Serafim, filha de Cicílio Paulo, mas esta também lhe falta. Estavam há quase meio século juntos quando ela morreu, num acidente de carro. "Mas eu não gosto nem de alembrar fia, porque é só alembrar parece que tô vendo o caixão de minha véa saindo agora... ai, Deus. ... Tudo que eu tenho aqui foi eu mais ela que fez". Tereza também era nascida e criada em Volta Miúda, "a fazenda dela era daí do outro lado, ali no pé de coco".

À frente não há mais pé de coco, somente pés de eucalipto. Antes, dava de tudo, "só não dava o que não planta.". Mandioca, muito abacaxi, laranja, cana, banana e tinha muita mata virgem, a Volta Miúda era terra rica, toda a redondeza até o Rio Peruípe. "Mas agora, se você plantá sua rocinha de maxixe, periquito come tudinho. De primeira não dava isso, né? Mas agora tá tendo esses inseto, mas também tem razão porque por eucalipto, quem vai comê só pau?". 
Aos 82 anos, Seu Domingos Serafim tem "sentimento" por muito do que não há... Mas ele gosta de relembrar o passado, "quem é que não gosta de uma coisa boa?". Foi-se a companheira, irmãos, filho, a visão, a fertilidade... Pergunto se Volta Miúda já foi uma comunidade feliz. Ele responde sem pestanejar: "É feliz". E, ao seu lado, diante do mar de eucaliptos, esforço-me a ver o mundo pelos olhos de Domingos Serafim.

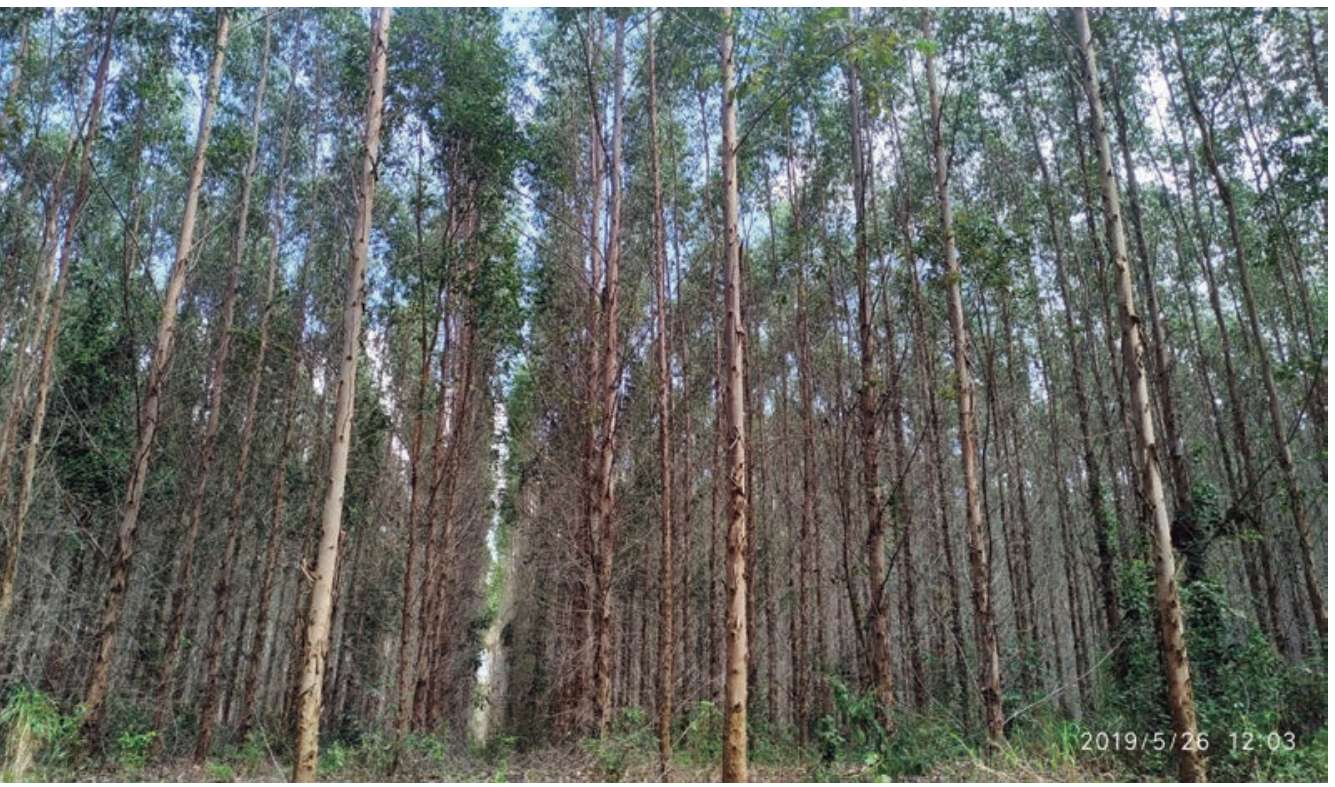

12 - Horizonte de eucalipto (2019). 
"Quando eu tomei entendimento de gente, ainda topei o cheiro dos escravo", criado na barra da saia da avó Júlia, ouviu muitas histórias, histórias que parecem aprimorar o sabor da liberdade. "Nasci e criei na Volta Miúda, e é daqui pro cemitério", Seu Domingos Serafim não quer ir a outro lugar, a sua vida está enraizada ali, há muitas gerações. Sua fala soa como afirmação e prece, afinal, não faz muito tempo, os pais dos seus avós sofreram nas mãos dos senhores latifundiários escravocratas que, naquelas terras, os escravizaram.

"Vó Júlia falava que com escravo era assim: botava, futucava formiga preta e botava criança lá, pra formiga preta mordê... não podia chorá, é verdade, escravo disse que foi duro, e hoje tem, tem uma catingazinha um cheirozinho de escravo". A senzala ficava ali pertinho do rio Peruípe, assim contava o pessoal mais velho quando saía para pescar. $O$ tempo de castigos passou, mas a ameaça à liberdade de permanecer em seu lar ainda o assombra, mesmo agora, ainda é possível sentir o cheiro.

A vó, que fazia "aqueeeele dendê", alertava os netos, "Eu tenho muita história, eu e meus primos-irmão". E Seu Domingos aprendeu, é "respeitadô do direito de quem merece". Foi ouvindo e vivendo e participando que aprendeu que a barbárie não desumaniza, a menos que se anseie o lugar do opressor. "Escravo trabalhava embaixo de taca, dona Raíssa. E se criancinha chorasse mãe não podia pegá, ia direto pro forno. É coisa de doido, né?". Seu Domingos, pondera: "Homem de capacidade num grita com outro, porque só se grita com gado". 
13 - Gente não é gado (2018). 


\subsection{BERTA D'AJUDA}

A neta da parteira Dominga é sabida que só vendo diz que a memória não é boa, que não sabe contar história... Mas Dona Berta d'Ajuda sabe contar história com a força e eficiência de quem trabalha na roça, de quem sabe fazer farinha, moqueca, dendê e até casa de taipa.

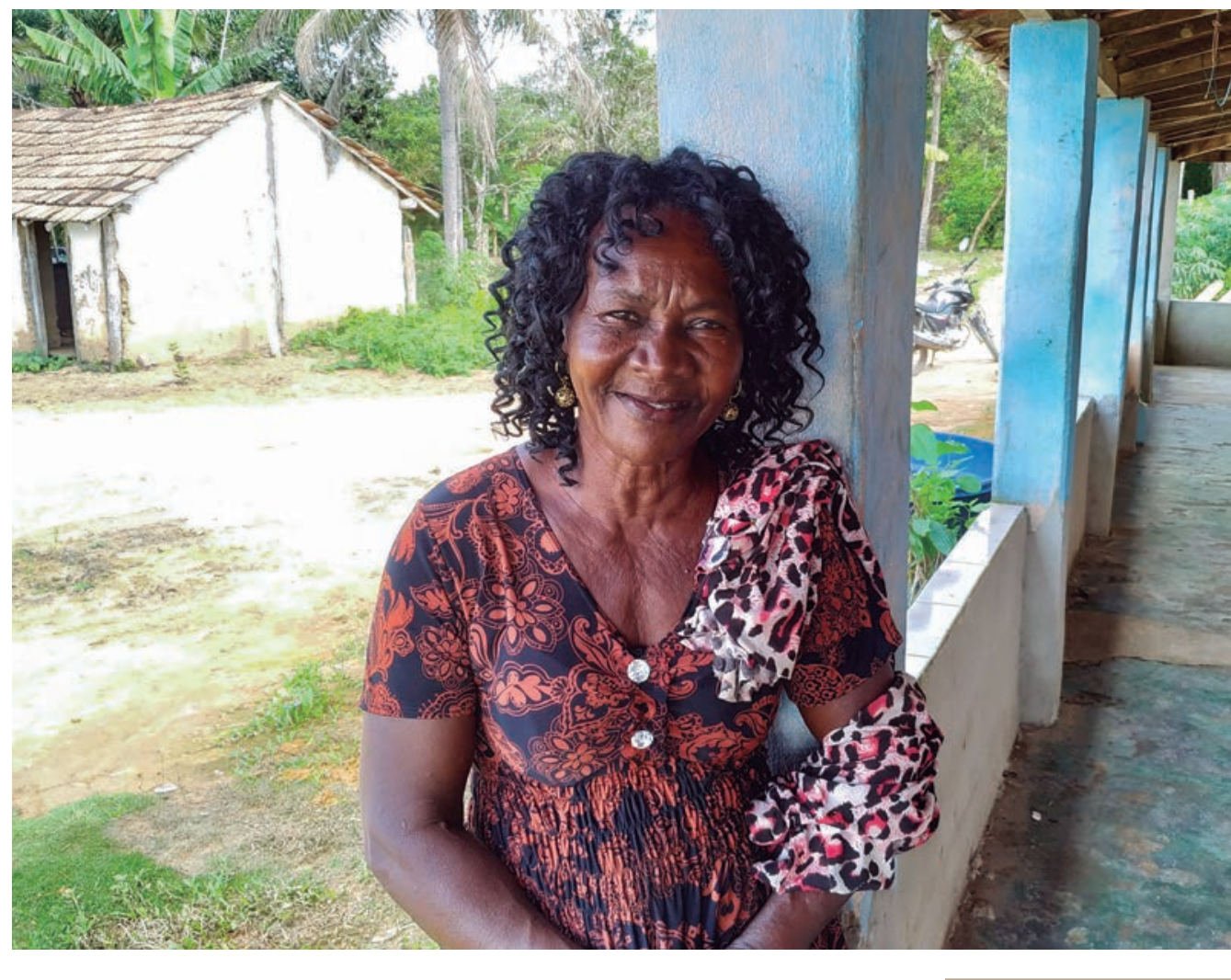

14 - Berta d'Ajuda (2019). 
Descascando coco para fazer beiju, a timidez vai ficando para trás e ela confessa: "Na verdade, ai dos homi se num for as muié... As muié é que é guerrera". Com voz firme, ela conversa sem parar de trabalhar.

A vida é dura, mas é muito bonita também... Ir à rua, só para vender as coisas e passear, bom mesmo é viver na roça, onde tem muita gente entendida e tudo é "muito bonito, é sim, dona menina".

A Volta Miúda é o lar de mulheres valentes, que enfrentam a batalha, com certo orgulho e melancolia - "se as muléficar decaída vai ficar sozinha à toa". Todo sábado Dona Berta está na feira, vende beiju, tapioca, feijão-de-corda, aipim, "de tudo que a roça produzir". Vende o que planta e as mercadorias do filho.

"Hoje a gente vive mais sozinho", a saudade de Dona Berta fala de uma Volta Miúda diferente, dos tempos da infância e juventude, quando "o pessoal era muito unido, era muito unido, agora não é tanto mais assim. É unido, mas num é igualmente". Ela aprendeu a ajudar a quem precisasse, pois antigamente era assim, "mais hoje em dia os novo só qué sabê do dinheiro".

Todo mundo ajudava a todo mundo. Quem precisasse ia chamando: "Olha, eu vô fazê um negócio tal dia, assim, assim"... No dia marcado, a panela de feijão ia para o fogo, carne, "tudo chegava, trabalhava, quando dava na hora de almoçá, almoçava, tomava café e de tarde ia embora". Se ficasse serviço para o outro dia, ajuntavam-se novamente. "Era bonito". 
Dona Berta sente saudade do tempo da casa de palha, - quando "todo mundo ajudava, o pessoal perdia tempo pra ficá a semana toda ajudano você fazê qualquer coisa" -, Dona Berta sente saudade do tempo em que o dinheiro ainda não havia corroído as relações - "ajudava de graça, hoje em dia, ninguém qué disprendê hora pra ajudá". Mas ela garante que o povo ainda é unido, mesmo que não seja como naqueles tempos. "Era muito unido, agora num é tanto mais assim. Intão é, só num é igualmente", e persiste o orgulho da sua terra e do seu povo.

Foi vivendo com os seus, participando desses ajuntamentos, que Dona Berta aprendeu a fazer casa de barro, aprendeu a fazer beiju e moqueca, cuidar da roça e fazer dendê. Aprendeu vivendo.

A Volta Miúda tem muita gente sabida. Dona Berta me olha como a quem "ainda tá fedeno a leite", e conta: foi sua avó que fez o parto dos seus filhos. "Todos cinco passou na mão dela", e naquela época ninguém morria, pois nascia na mão das mães que geravam a comunidade. "Era tudo sabido, minha avó Dominga tinha idade, era uma partêra boa, morreu velha já. Chega a hora pra todo mundo, num tem jeito". Se antes os pais que governavam os meninos, hoje os tempos já são diferentes... Mas os netos que moram com Dona Berta estão crescendo direitinho, estão aprendendo que não se vive sozinho, e que pra se morrer sozinho basta muito pouco. "Ai de mim se num fosse esses menino, de vez em quando tem as malandrage deles, mas me ajuda dimais da conta".

Dona Berta é uma mulher inteligente e acha que, se os novos não aprendem o labor dos velhos, é porque ou lhes 
falta interesse em ouvir, oportunidade para viver ou interesse em permanecer na lida da terra. Mas ela garante: "a vida na cidade só presta pra quem tem bolso cheio, eu prefiro ficá na roça". A roça dá o alimento e o teto. Para quem não teve ou perdeu a oportunidade de aprender a construir seu próprio lar, Dona Berta ensina como fazer casa de barro: "Cava o chão, procura assim lugá que tem barro vermelho, e aí junta. A gente chama os pessoal, junta esse povo todo de gente, leva a vasia pra levá água, chega, põe e aí vai ajudano. Aí os homi corta o barro, tem hora que as muié caía no meio também, cortava o barro, jogava água, massava e ia carregá pá tampá a casa. O telhado era de palha, ou de palha ou de madeira ou de ternit, mas era mais de palha. Eu mesma, casei na casa de palha, e casei e morei na casa de palha quando casô, até tive os filho todinho, casa de palha".

Dona Berta fala sobre a casa, mas ensina mesmo é que os ajuntamentos - que também aconteciam na lida da roça, para capinar, colher, tratar... - eram a vida acontecendo e ensinando a meninada a ser gente e a servir... ensinando a ser comunidade. 

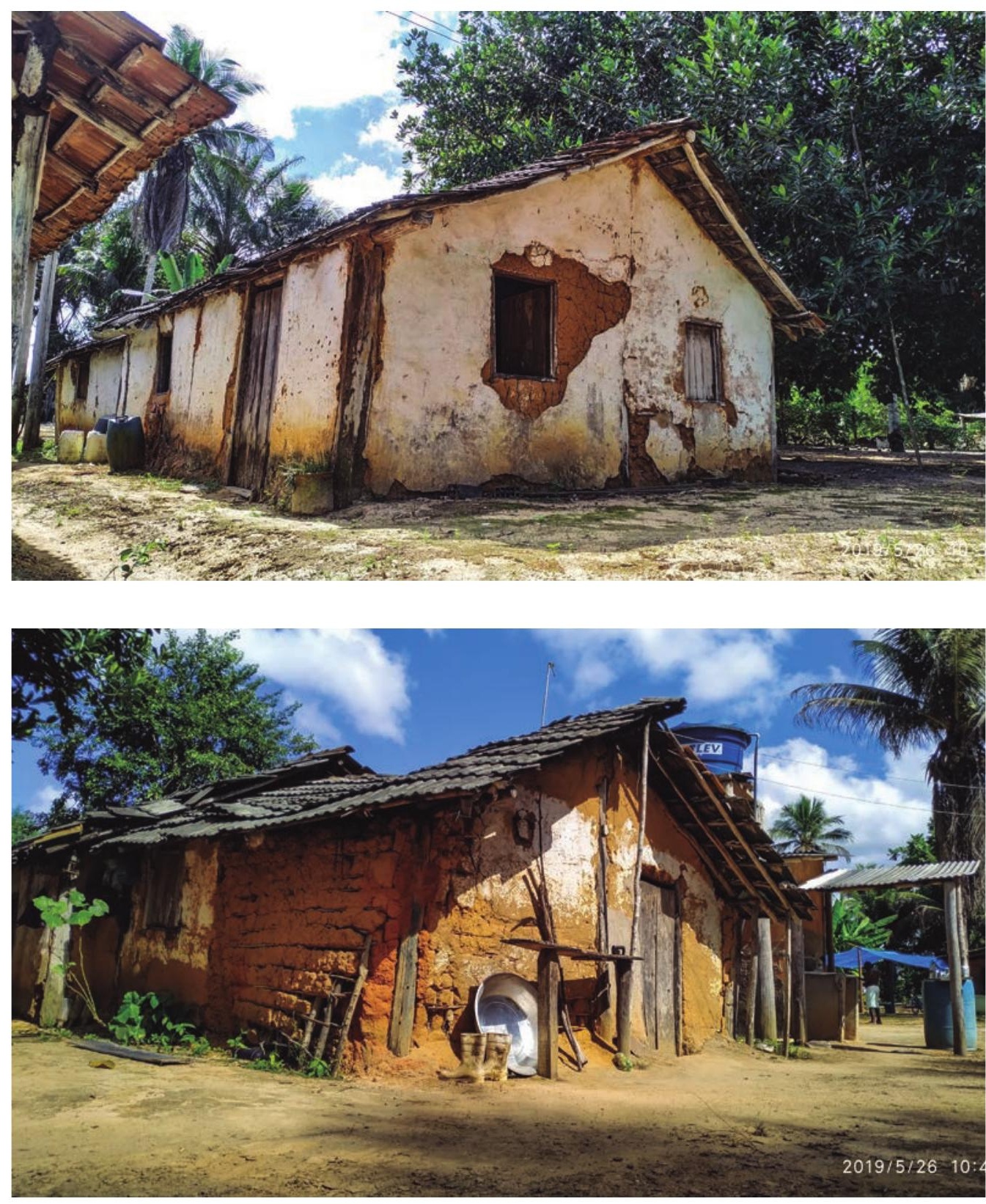

15 - Casa de Taipa

em Volta Miúda

(2019).

16 - Marcas do

tempo, Casa de 
Para ele, o mundo tem muita gente - e, por isso, falta alimento.

As máquinas substituem os homens no serviço - mas, se foi inventada, tem que funcionar. Se a mata está sendo derrubada é porque antes tinha pouca gente no mundo hoje tem muita gente para destruir. Existem ricos e pobres - e é bom que seja assim, afinal, quem ia querer "enfrentá a enxada com esse sol quente"?

"A gente acha que tá ruim, mais a coisa nunca fica bom pra todo mundo. Pra uns mais ou menos, pra outro tá bom, pra outro zero. Mas eu conservo assim mesmo, porque não tem jeito".

Seu Santinho Brasílio explica, paciente, o caos do mundo. A população cresceu, as máquinas foram inventadas e têm que funcionar - porque senão o serviço de quem as fez fica sem prestígio -, os ricos não iam querer trabalhar como negros, então tem mesmo que haver os pobres, do contrário aí é que ia faltar alimento mesmo - hoje, pelo menos, não falta para todo mundo.

"Tem gente que reclama, mais eu falei: ó pessoal, num tem jeito não", e, se não há jeito, tudo está como deve ser e, se faltam motivos para comemoração -, não tem porque ficar amuado. "É assim que é".

O eucalipto chegou, deu emprego, as máquinas vieram para fazer o serviço render mais, chegou o desemprego, a água do lago secou - "mas talvez porque chegou o tempo tamém" -, mas agora tem transporte para ir à rua, a terra não rende mais o alimento, mas tem escola... 
"Mais o resultado é conforme eu tô dizeno, quando conserta um lado, entorta outro e num jeito de consertá tudo tamém não né. Não tem as condição de consertá tudo, né. O governo não pode consertá tudo porque não tem jeito, a população cresceu muito. Então ele não tem jeito de consertá essas coisa tudo não, leva a fama... mas a coisa pra ele também é bastante peso."

"É assim que é": sem tristeza, sem pesar, nem dor. Mas também sem esperança.

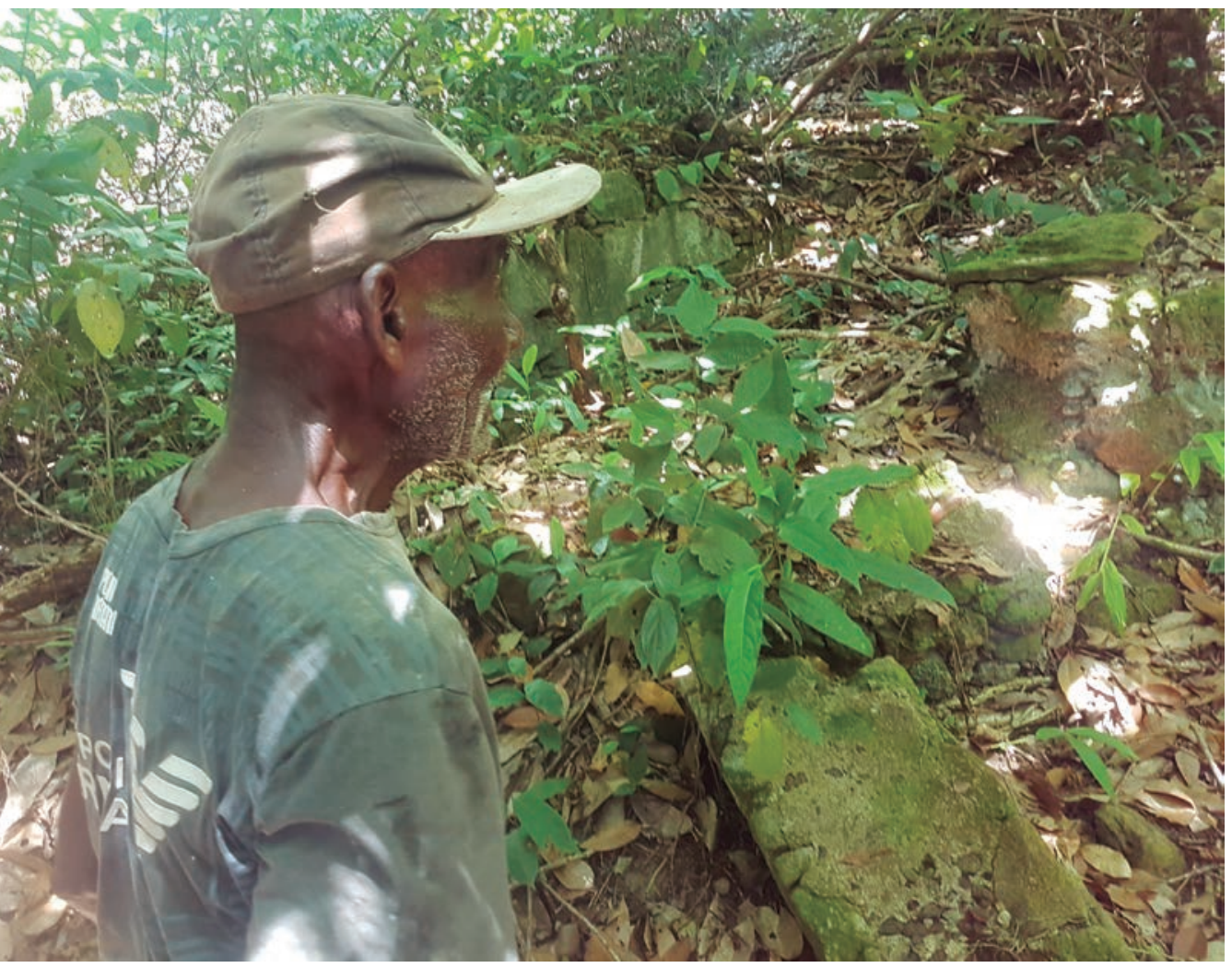


O irmão de Dona Brasília conhece o caminho para chegar ao local da "senzala", onde estão as ruínas do "engenho de fazê alambique, secadô de café, represa e roda d'água". Lá, jaqueiras e coqueiros se perdem no céu... são testemunhas seculares do labor dos bisavós e ascendentes de Santinho Brasílio.

"Tudo aqui foi feito pelos escravo" - como parte de uma história inevitável, assim como parece ser ainda hoje -, paredes de pedra vão se erguendo no meio da mata, e o que era nada faz-se significativo: "os escravo naquela época sofria muito".

Abrindo caminho na mata a facão, derrubando madeira para fazer pinguela, o vigor define Santinho Brasílio - vigor de quem trabalha e enfrenta a vida porque assim é que é, tem de enfrentá-la.

O maior enfrentamento, contudo, é a admirável substância e vida nas pedras que conformam arcos, canais... que conduzem a uma preservada escadaria e um terreiro. 


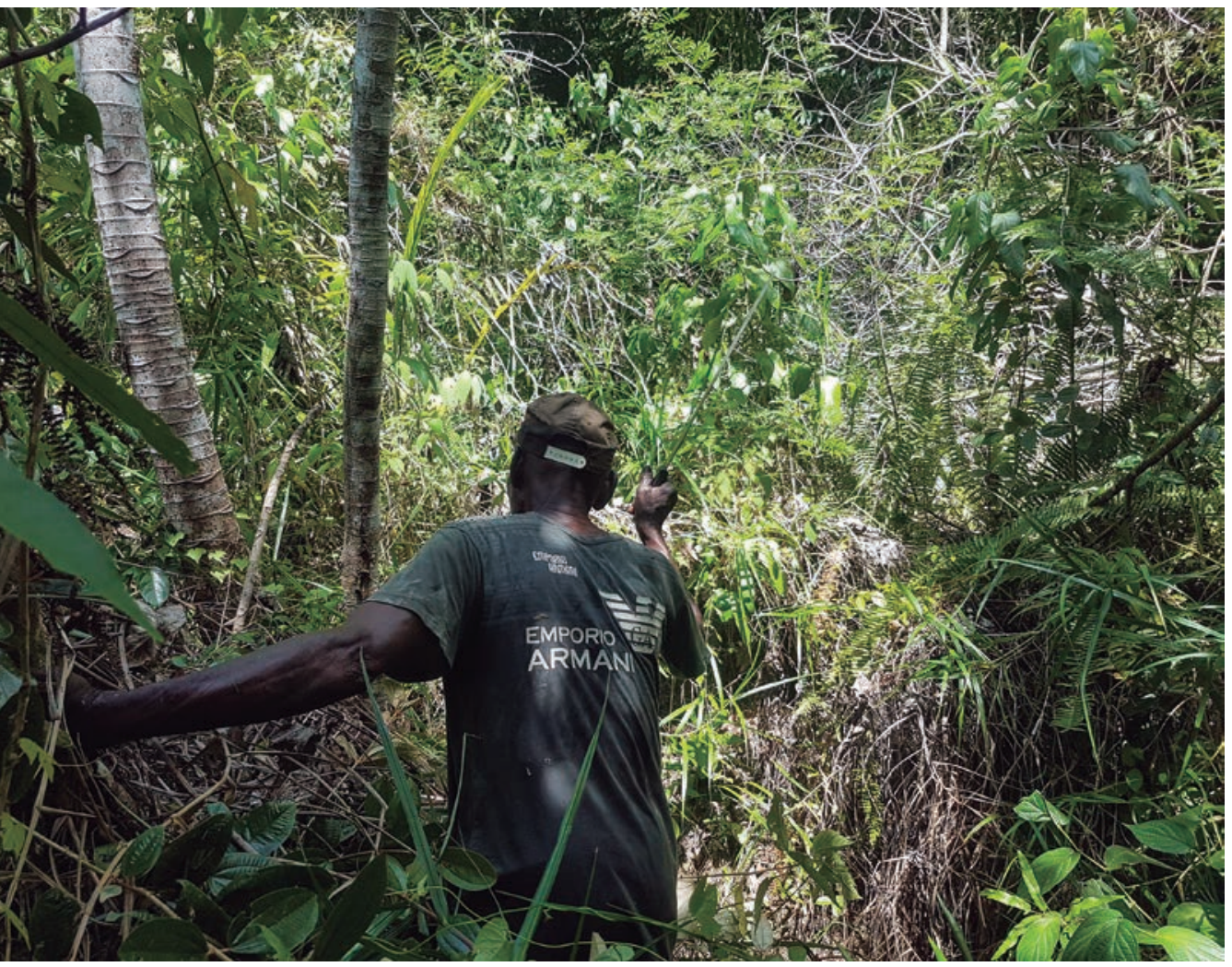

19 - Santinho

Brasílio abrindo

caminho na mata

(2019). 


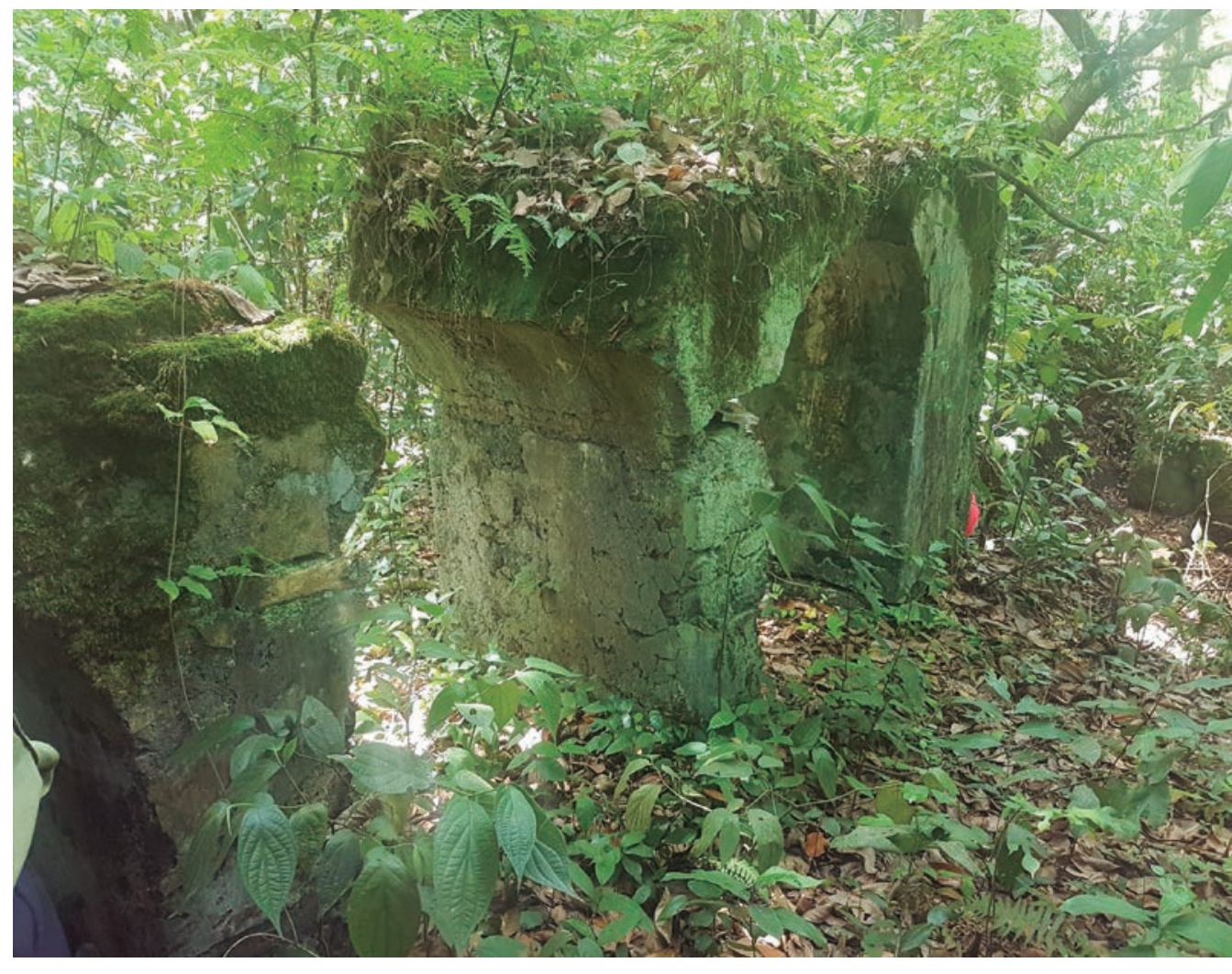

20 - Sítio

Arqueológico

Senzala de Volta

Miúda (2019). 


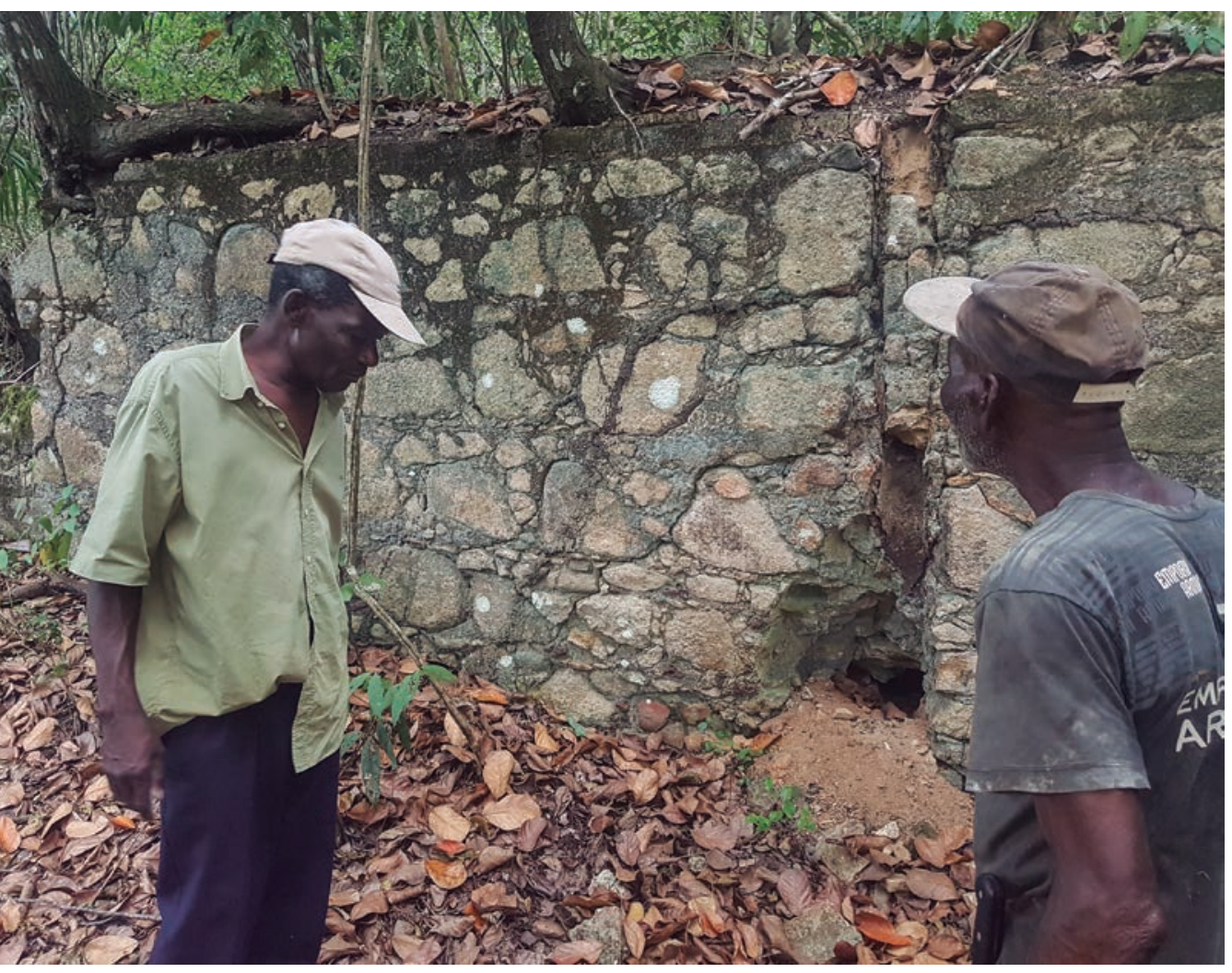

21 - Santinho

Brasílio e Manoel de

Delfina na Senzala

(2019). 


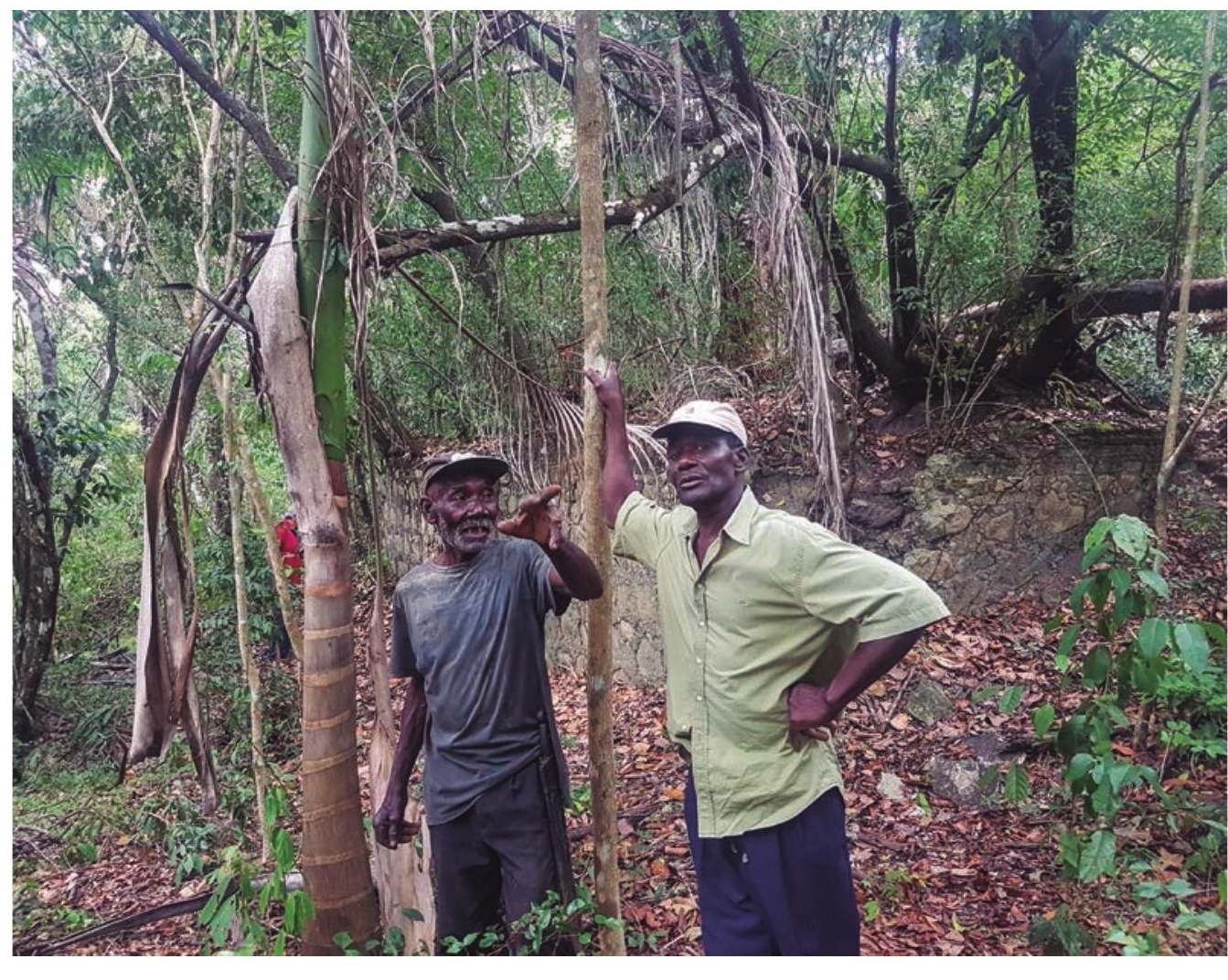

22 - Santinho

Brasílio e Manoel de

Delfina na Senzala

(2019). 
Histórias, achados, relatos de quase morte e vida da lagoa que secou e das grandes canoas que conectavam Volta Miúda à Villa Viçosa falam sobre a vida que erige a partir das pedras.

“A casa era lá ó... A casa, lá embaixo era bem alto. E era varanda, a casa tudo era varanda ao redó. A casa eu topei, mas só que não tinha gente mais, e tudo tinta azul, as parede, as madêra, tudo tinta azul", mas tudo se acabou. Havia enfeite, casa, rio e riqueza - tudo acabou.

É com o mesmo semblante ameno, dotado de certo tom de fatalismo, que Santinho fala sobre o ontem e o agora; o futuro será o que há de ser - um paradoxo de quem sente o mundo estatuado, por força do tempo ou das substâncias de vida que imobilizam e, a certo ponto, desumanizam ao tolher o arbítrio... "Tá vendo? Tudo pedra, oí ó. Tudo de pedra. A água tá fria. Água fria, só vendo. Agora tudo de pedra". 


\subsection{MIÚDA}

Miúda só no nome, ela nasceu pequenininha e isso valeu o apelido que carrega até hoje:

"Eu era miudinha, desse tamaninho... Minha mãe sempre falava, ela tinha um banco quando ela sentava ali pra cosê, e ela sentava e me botava. Chegava um e olhava por debaixo do pano: 'Ih, Delfina, essa aqui num vai criar não...o rosto dela é muito miudinho'. Aí eu fui cresceno, cresceno... começô a gatinhá, começô a sentá, aí começô andá, foi um ano, dois ano e tô eu aqui hoje".

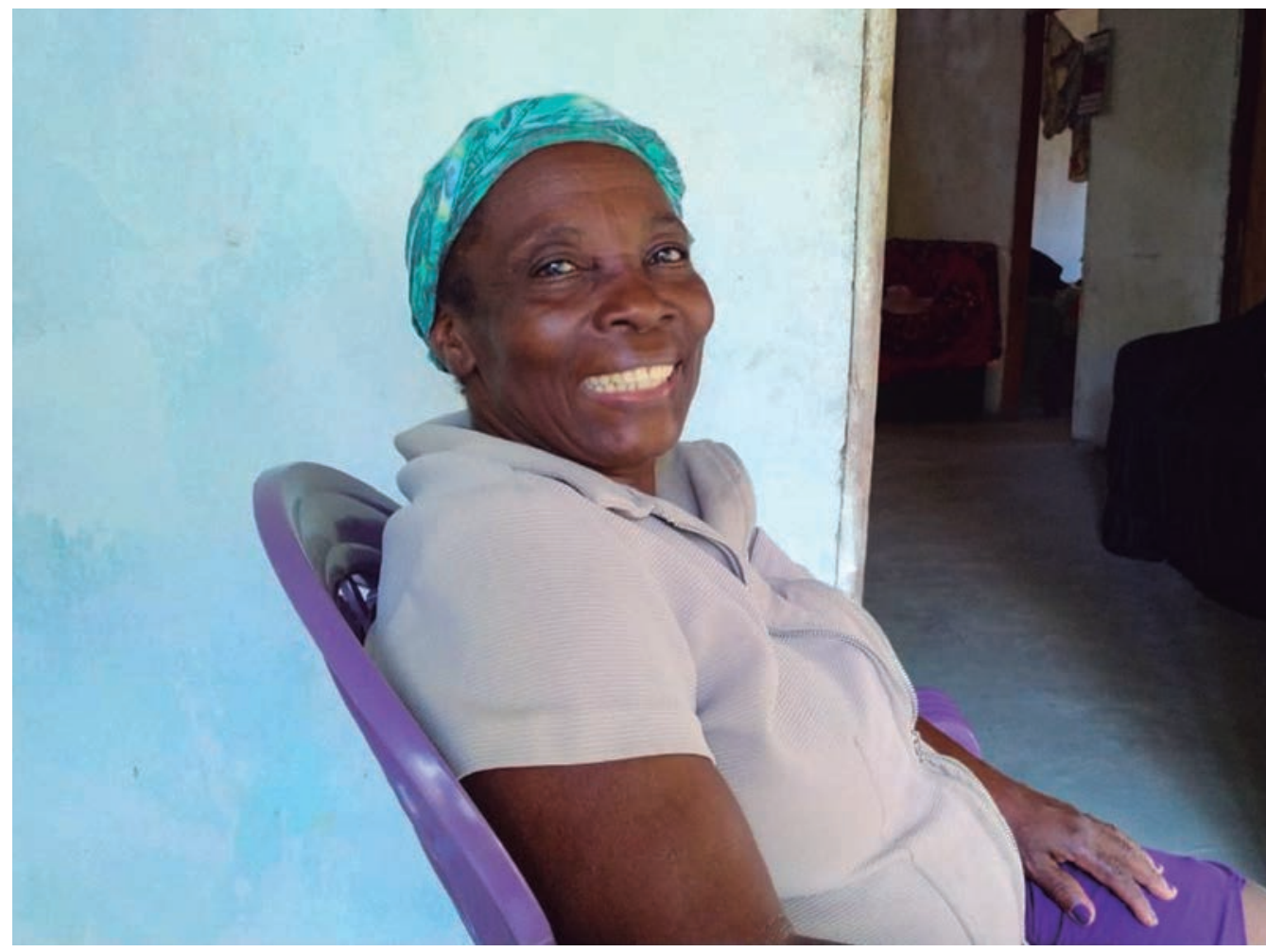


Dona Miúda é Romana Joaquina Serafim. Romana como a mãe do seu pai, José Serafim. Joaquina como a mãe da sua mãe, Delfina Josefa.

Dona Miúda é uma gigante em sorrisos (e riso) e abraço.

"Eu sou quilombola" - se apresenta. Sentada na varanda, jovial e desprendida, Dona Miúda conta sobre a família, avós e bisavós "do tempo do cativero", mãe e pai que viveram (e morreram) em casa de taipa, e dos netos a quem ela mesma está ensinando que são, também, quilombolas. Ela reconhece que na escola não ensinam sobre Volta Miúda, mas ela fala a quem quiser ouvir - assim, quem sabe, a(s) história(s) não $\operatorname{morra}(\mathrm{m})$.

"Meu neto mesmo veio esses dia, passô meio dia aqui comigo e disse assim: 'ô vó, eu num sô da família dos quilombola?". Dona Miúda antes de explicar, pediu-lhe que sentasse ao seu lado, longe do celular e da televisão, e o menino assim fez, atentamente.

“Eu falei assim: É. Você é, e sua mãe é bisneta dos quilombola. Tá me entendeno?". Dona Miúda lhe ensina que a substância da sua vida é, por princípio, sangue e sentimento, os que antes dele vieram.

Na escola, foi assim que ele contou, mas os coleguinhas não acreditaram. Então, "Ele tirô o meu foto e levô, porque ele é da sua cor e eu sou preta - e eu falei num tem nada porque o sangue é o mesmo. Tá entendeno?". Dona Miúda, mulher preta, Ihe ensinou que a cor é um retrato, mas o que o define é sua história, sua cultura, o seu povo. Dona Miúda é afeto e fé. E também é força, é o que foi, o que há e o que há de vir. Dona Miúda é resistência. 

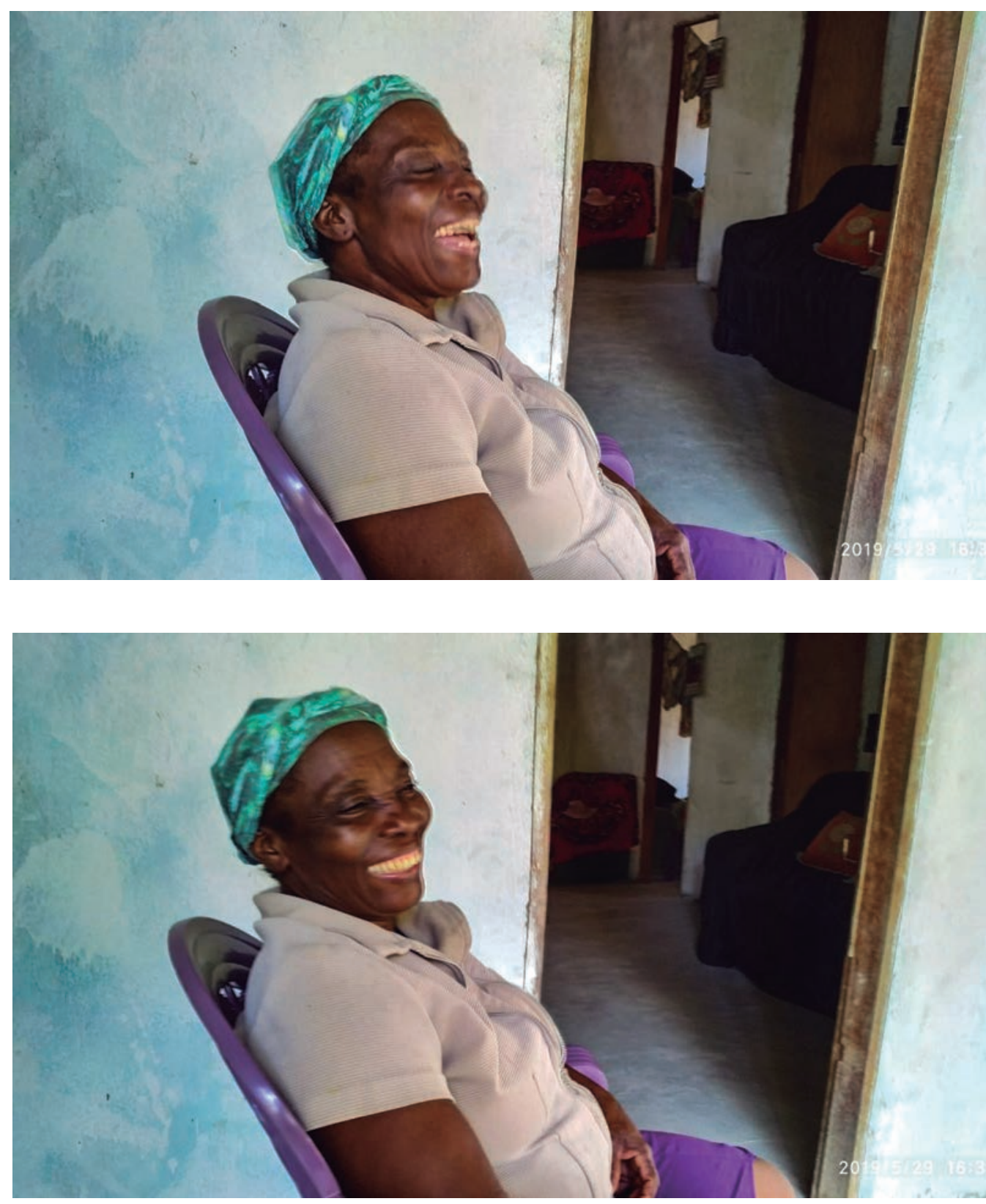

24 e 25 - Miúda

e o seu largo

sorriso (2019). 


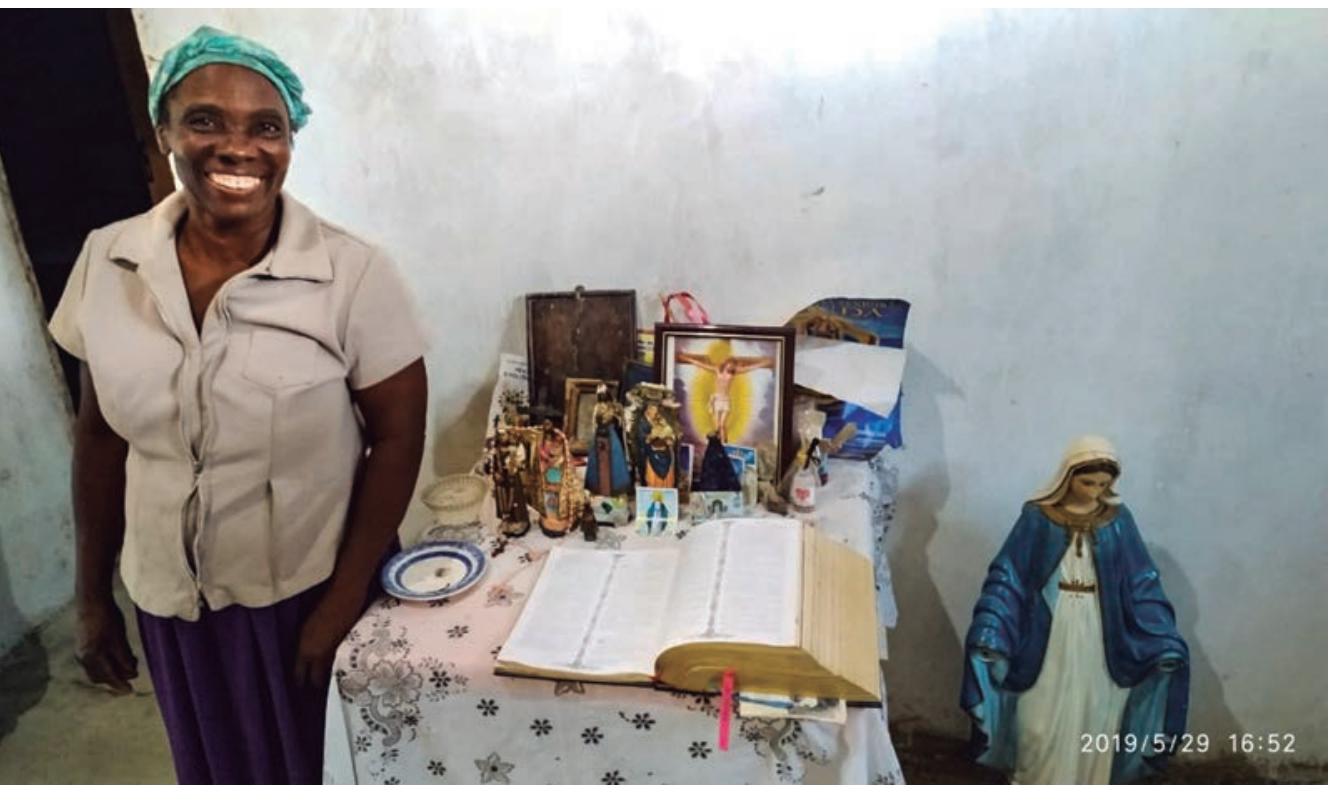

26 - Miúda, a seu

pedido, ao lado do seu oratório (2019). 


\subsection{ZELITA}

De andar e fala ligeiros, Dona Zelita está sempre fazendo algo. Carregando coco no carrinho de mão, rezando na igreja, limpando o terreiro, indo à rua... a vida se passa em movimento. O ritmo, entretanto, não impede que sempre pare e pergunte: está tudo bem, quer um cafezinho?

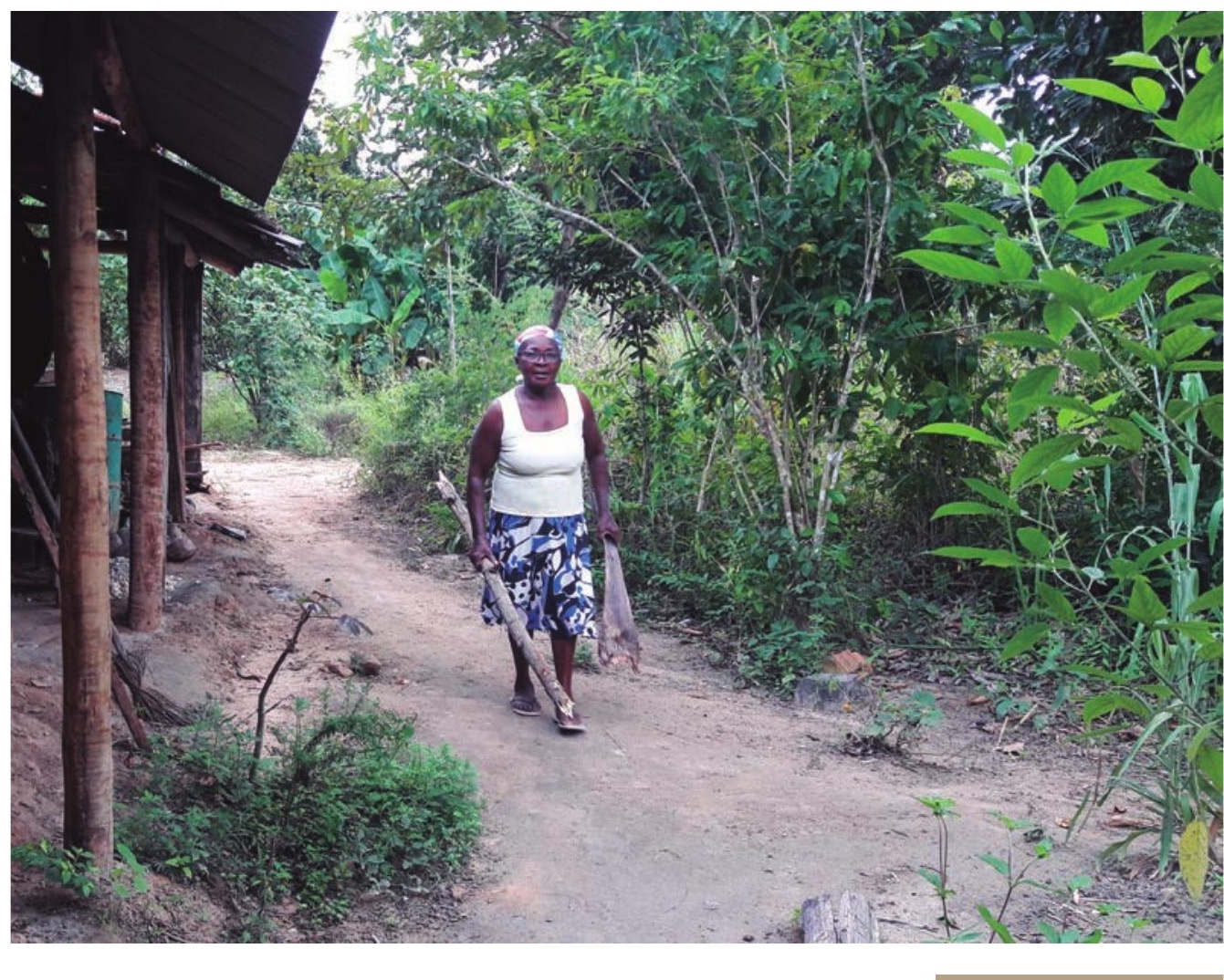

27 - Zelita

(2019) 
Dona de um humor peculiar, ela cuida da lida na roça, sabe fazer dendê e farinha, sabe muito. "Lá ele..." - diz ela, quando parece discordar de alguma coisa. Dona Zelita segue a vida fazendo o que precisa, mas sabe o que quer... vive o presente, mas sente, vigorosamente, a saudade.

"Ah, de vez em quando a saudade é tão grande, tão grande, que dá vontade de juntá meus pano e ir embora", mas o "embora" não é lugar. Ela fala sobre a família que vive longe, fala sobre os que já cumpriram seu tempo e se foram... "E é uma saudade tão grande que dói tudo por dentro".

Para conter a saudade, o melhor é ocupar a mente. Dona Zelita é ligeira e calada, de um abraço forte e contido. A lida lhe é tão natural que chega a duvidar que alguém não saiba fazer farinha... Mesmo desconfiada ela explica: "colhe a mandioca, rala, põe na prensa, passa no motô, penera e leva no fogo a lenha para secá, penera de novo e põe para torrá". A descrição ligeira só não fala sobre a força, asseio e inteligência necessários para fazer o ouro branco em pó.

Na companhia de Miúda, o trabalho começa cedo... As duas se juntam para compartilhar a dança: 

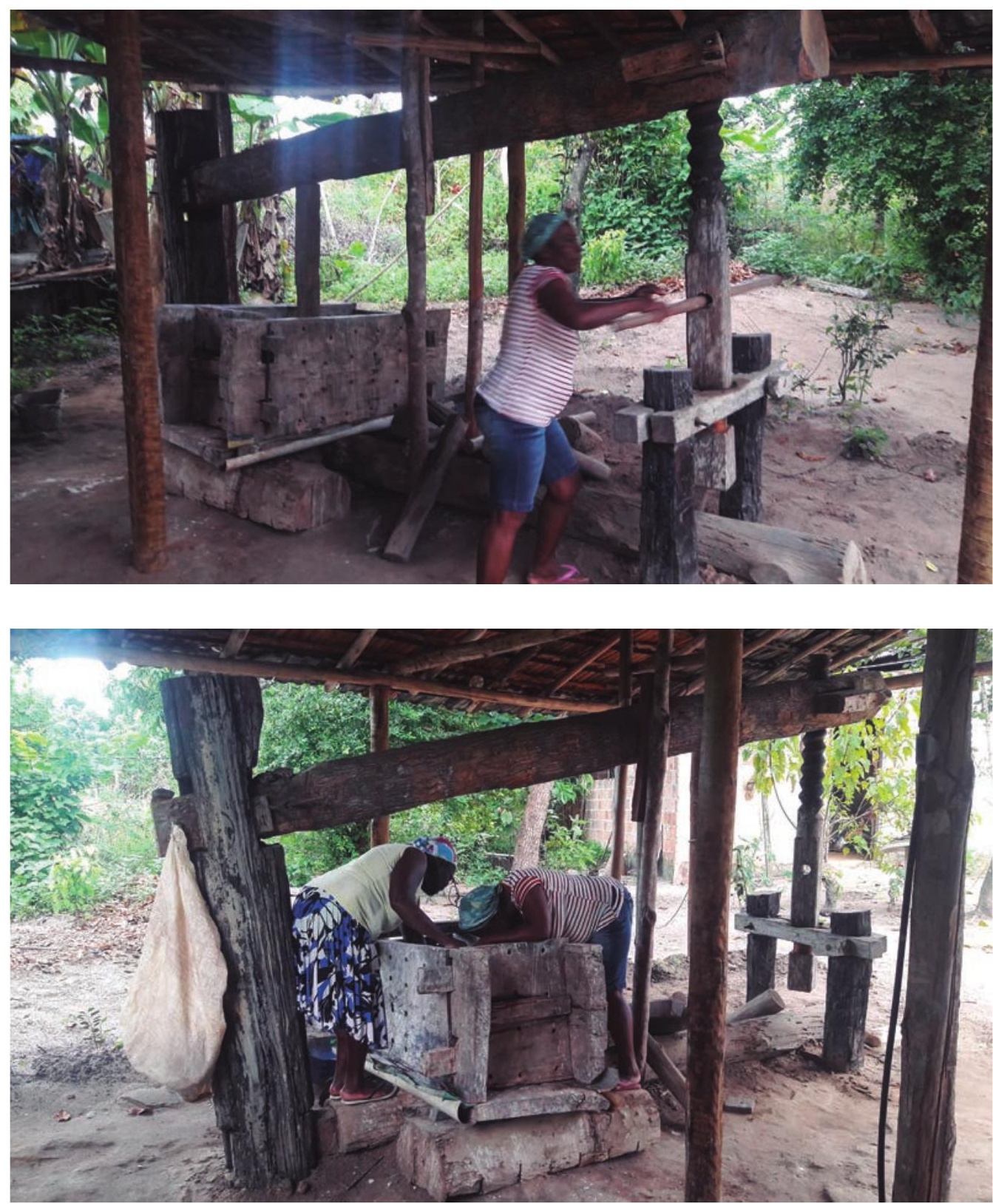

28 a 45 - Fazendo

farinha de Mandioca

(2019). 


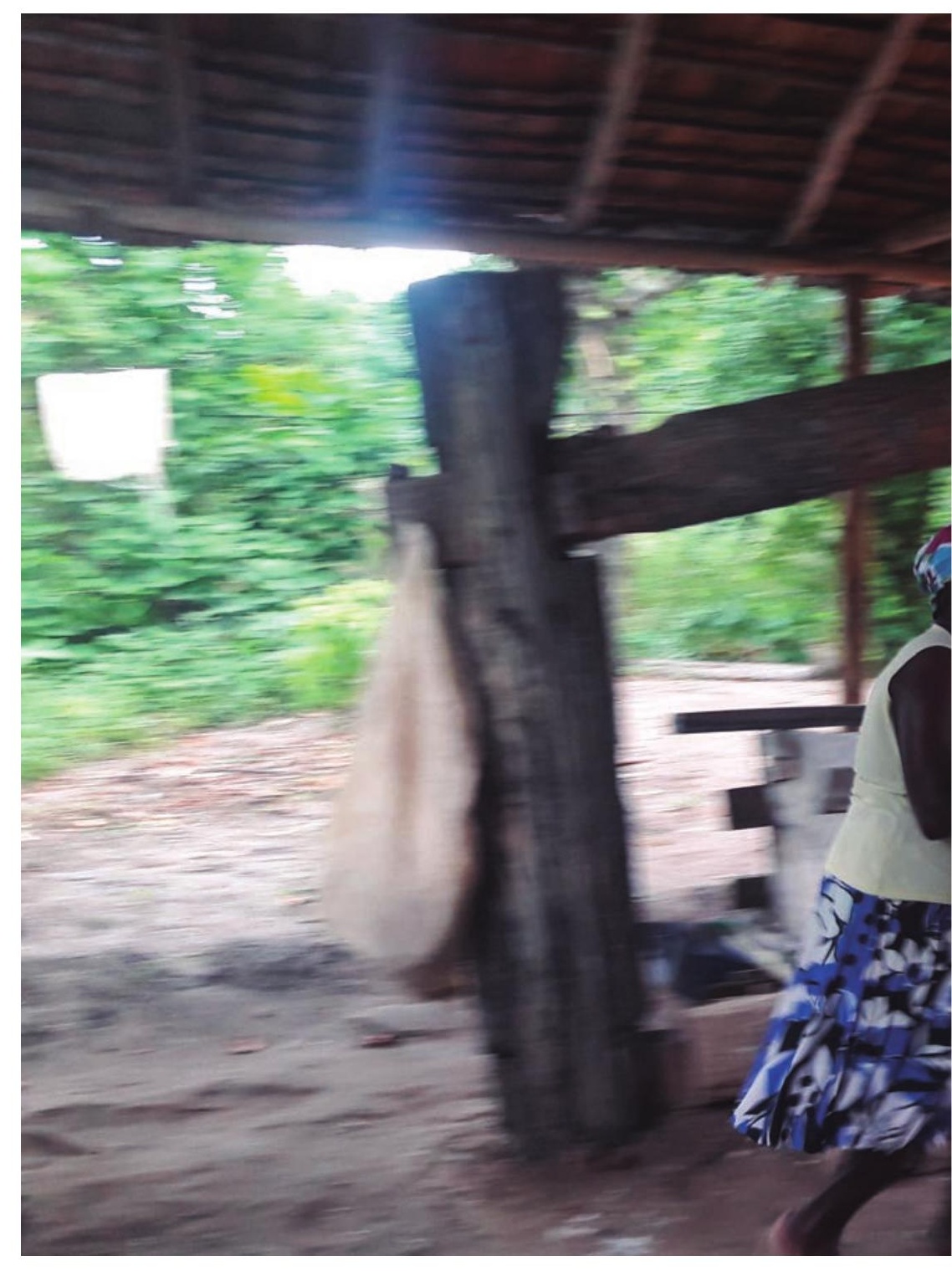

122 


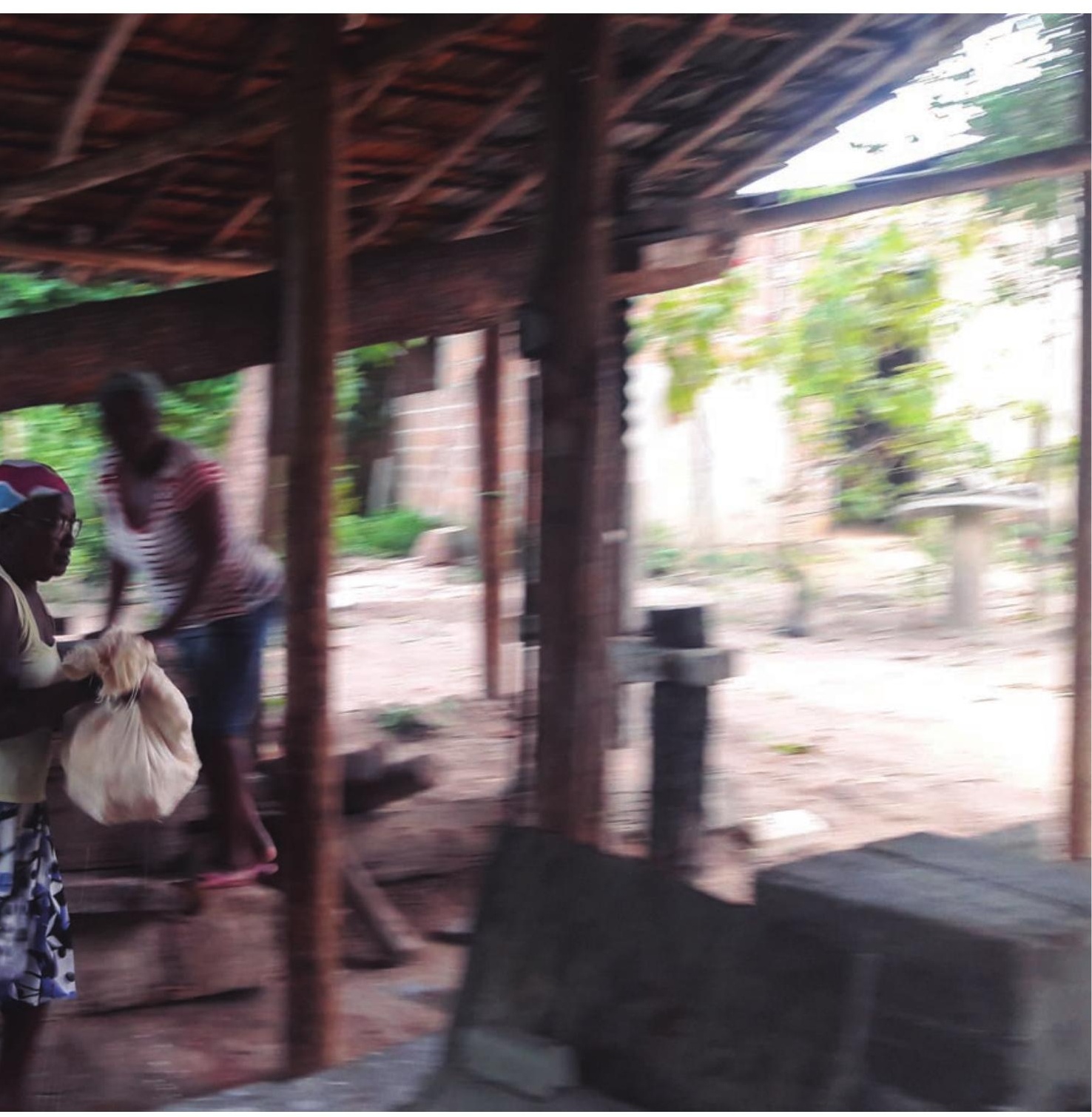



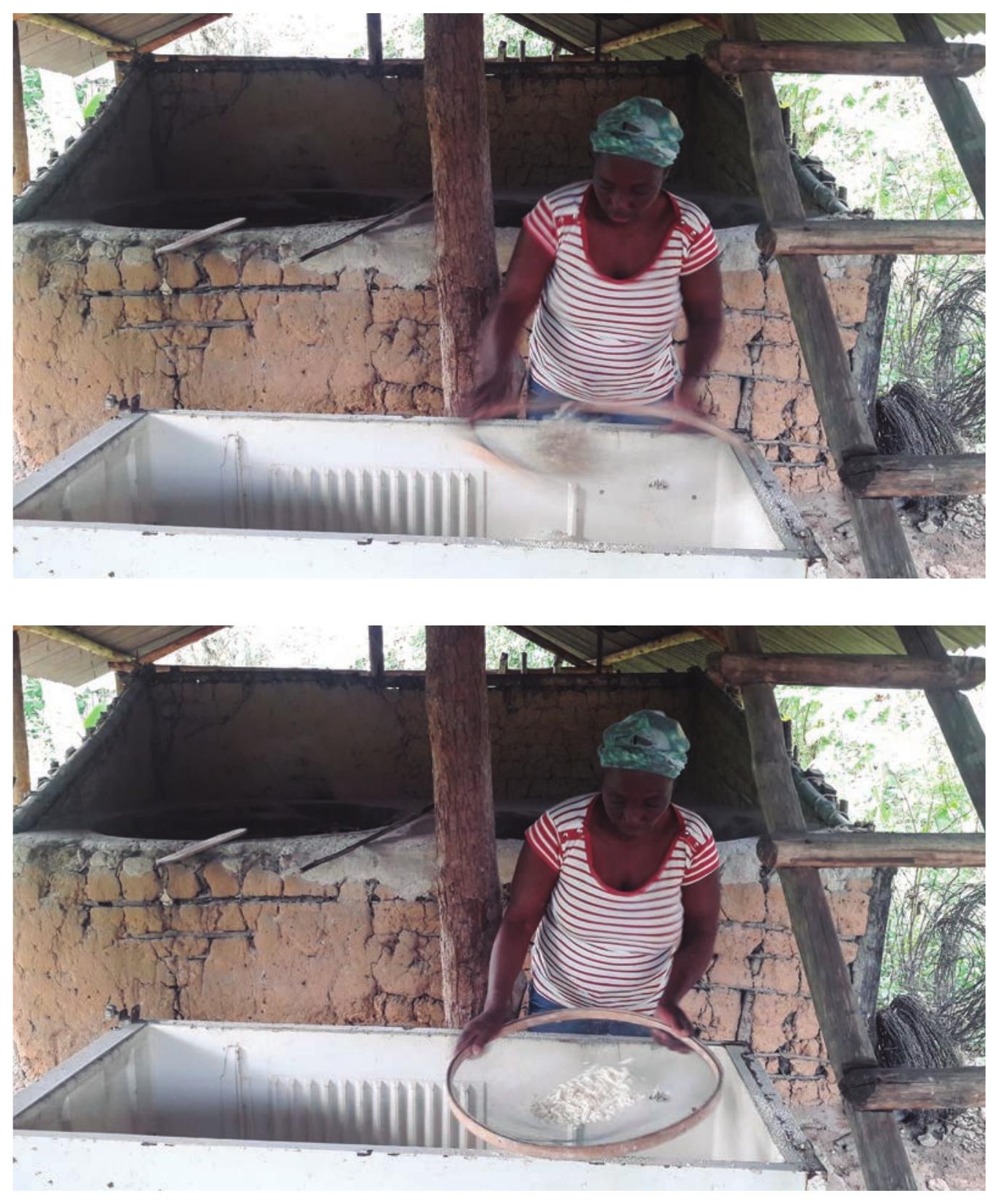

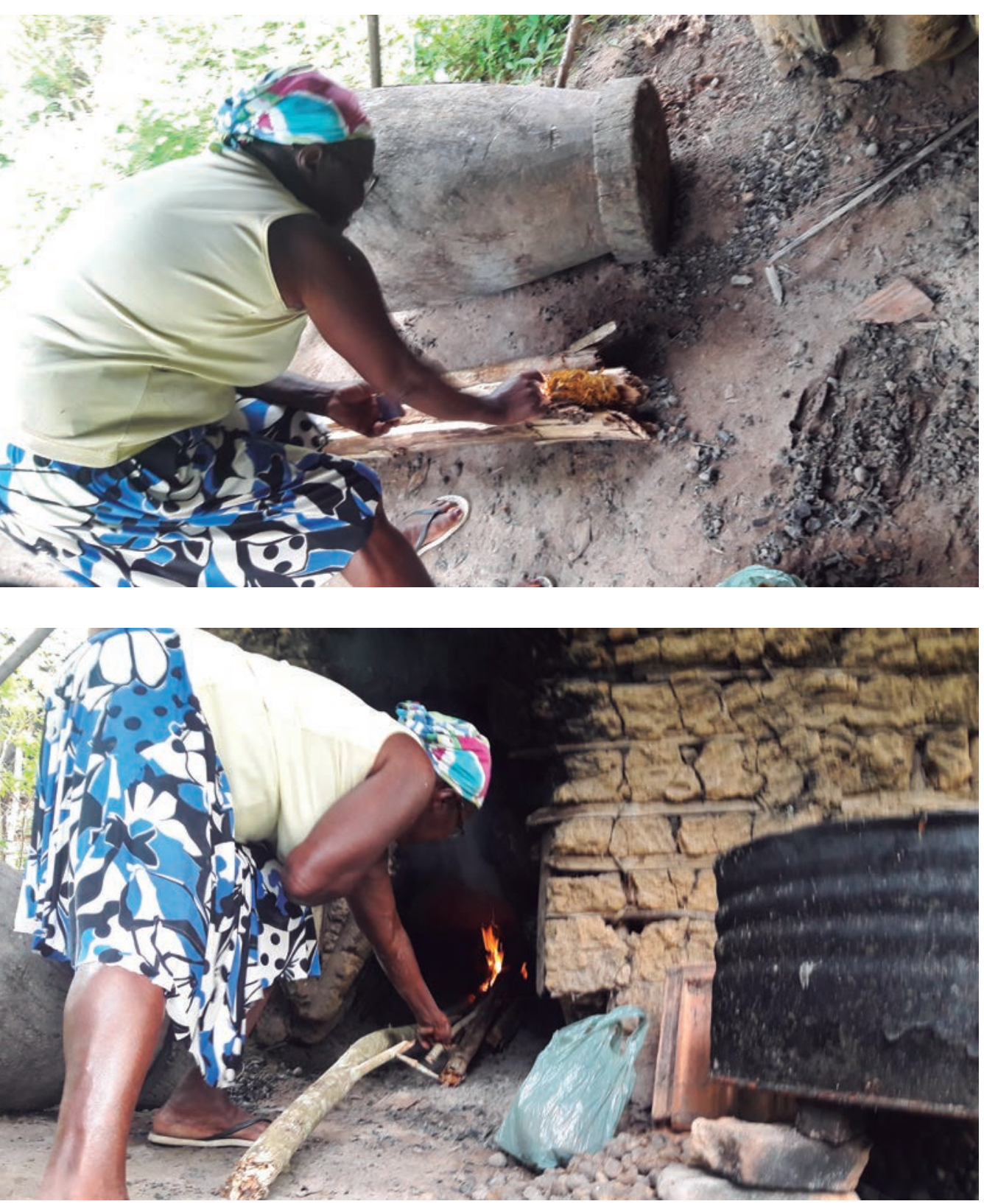

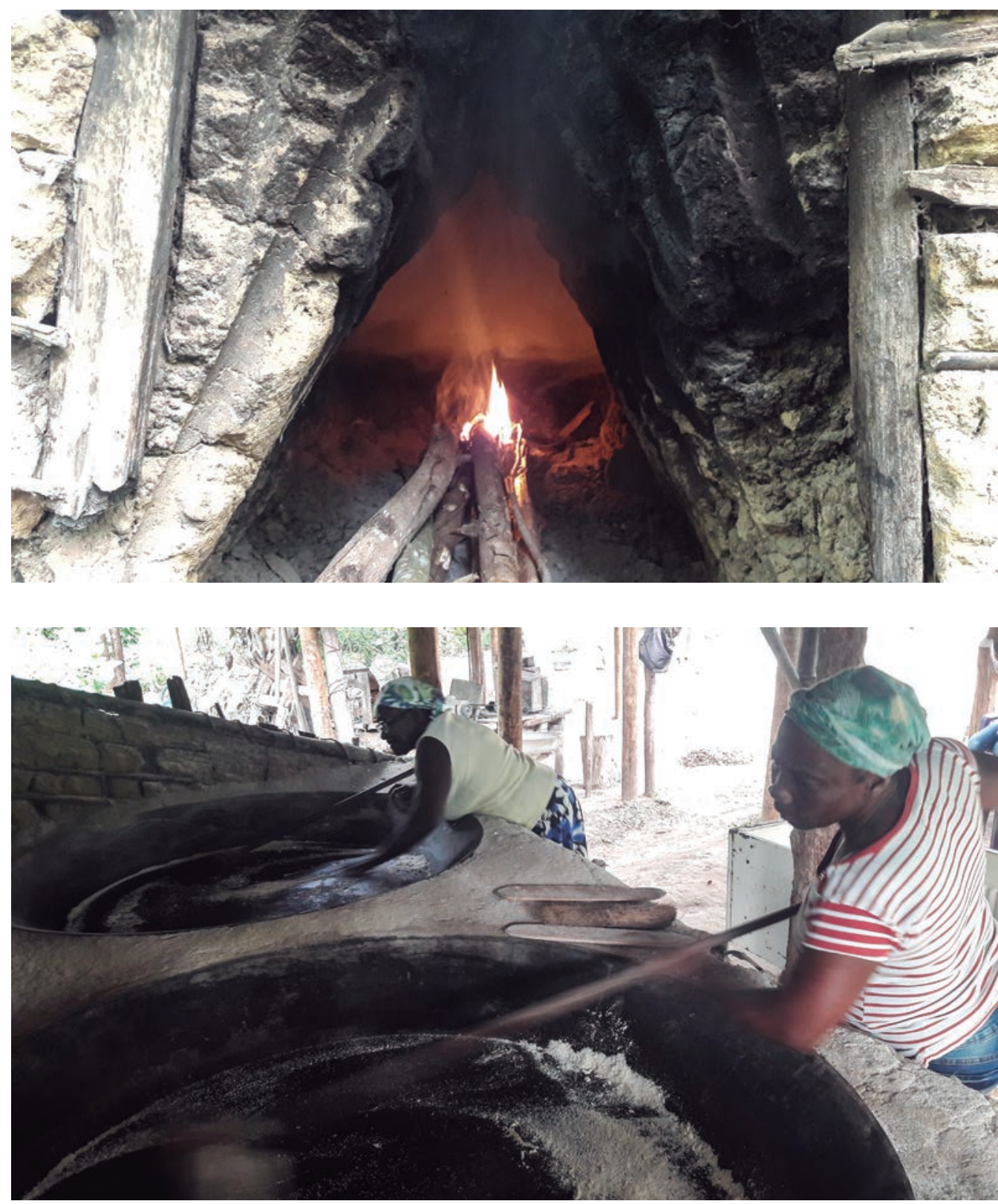

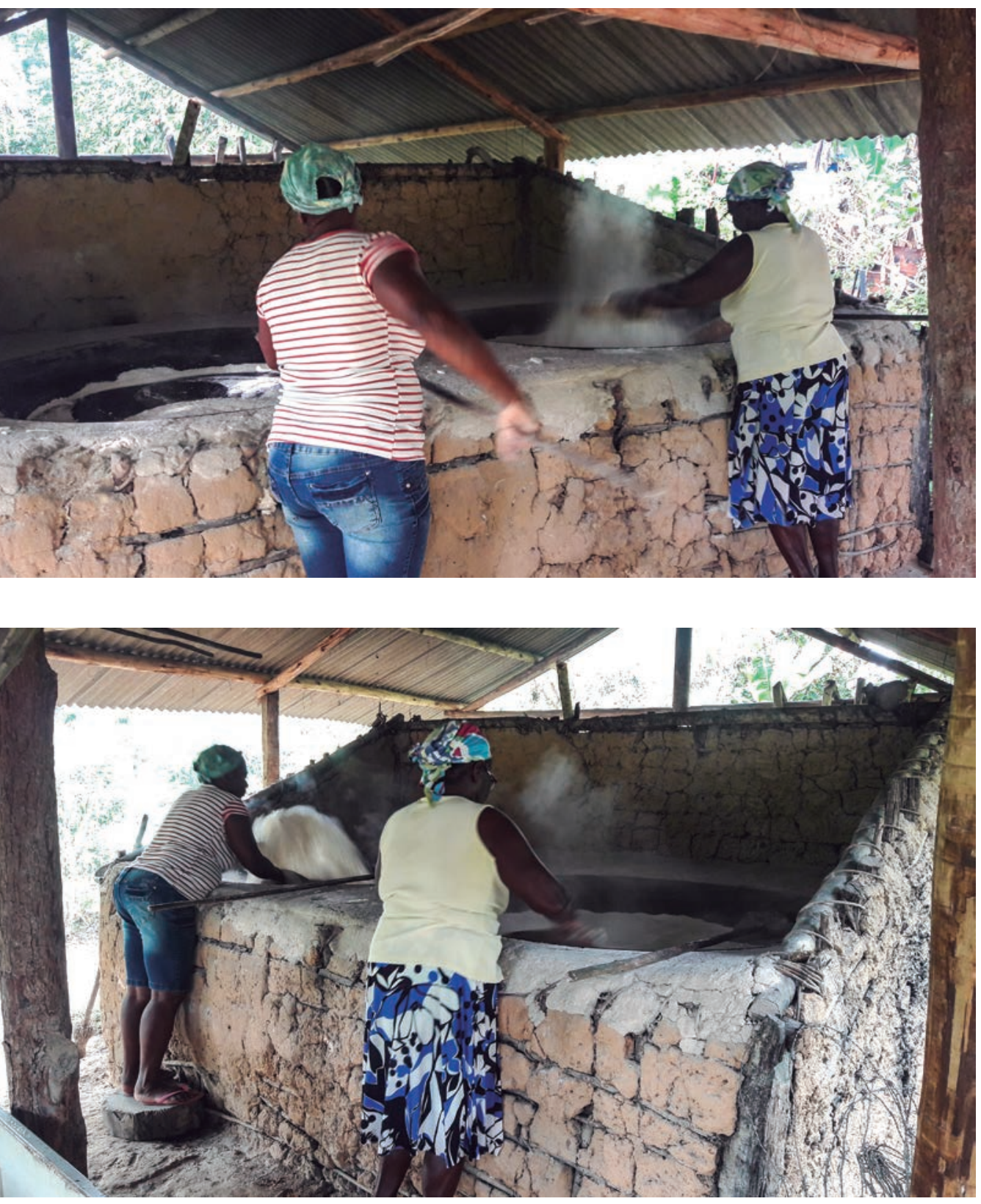

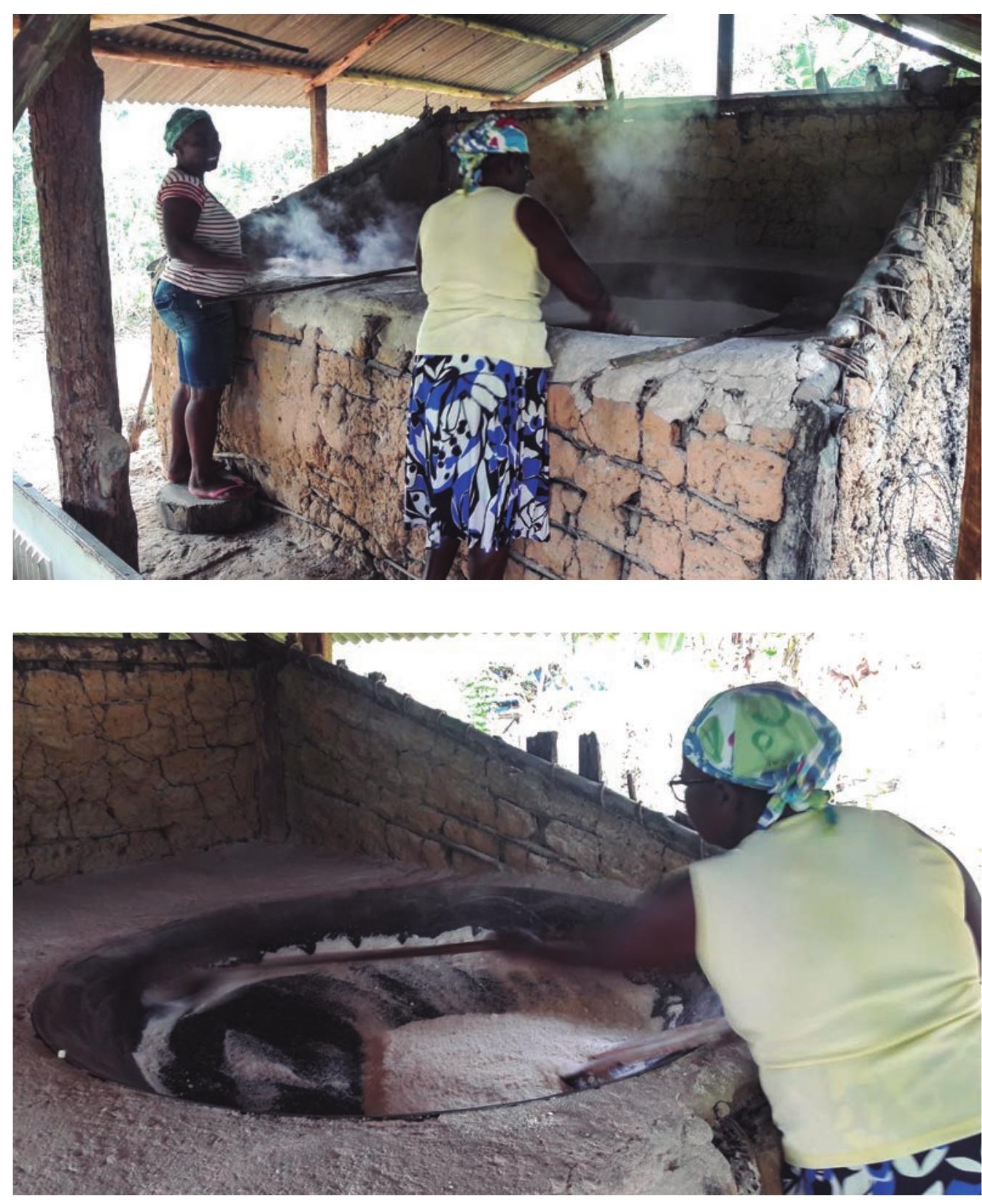


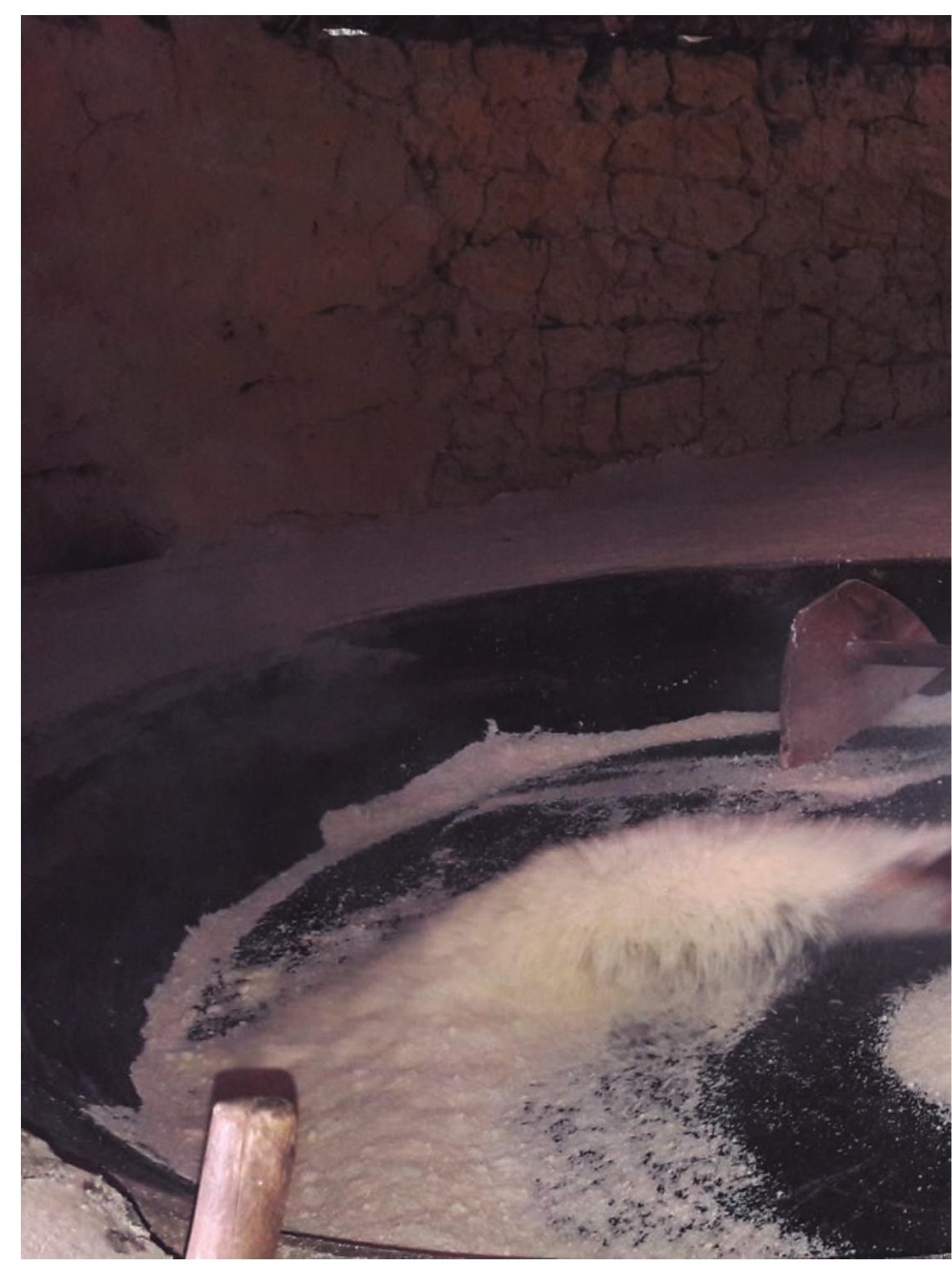




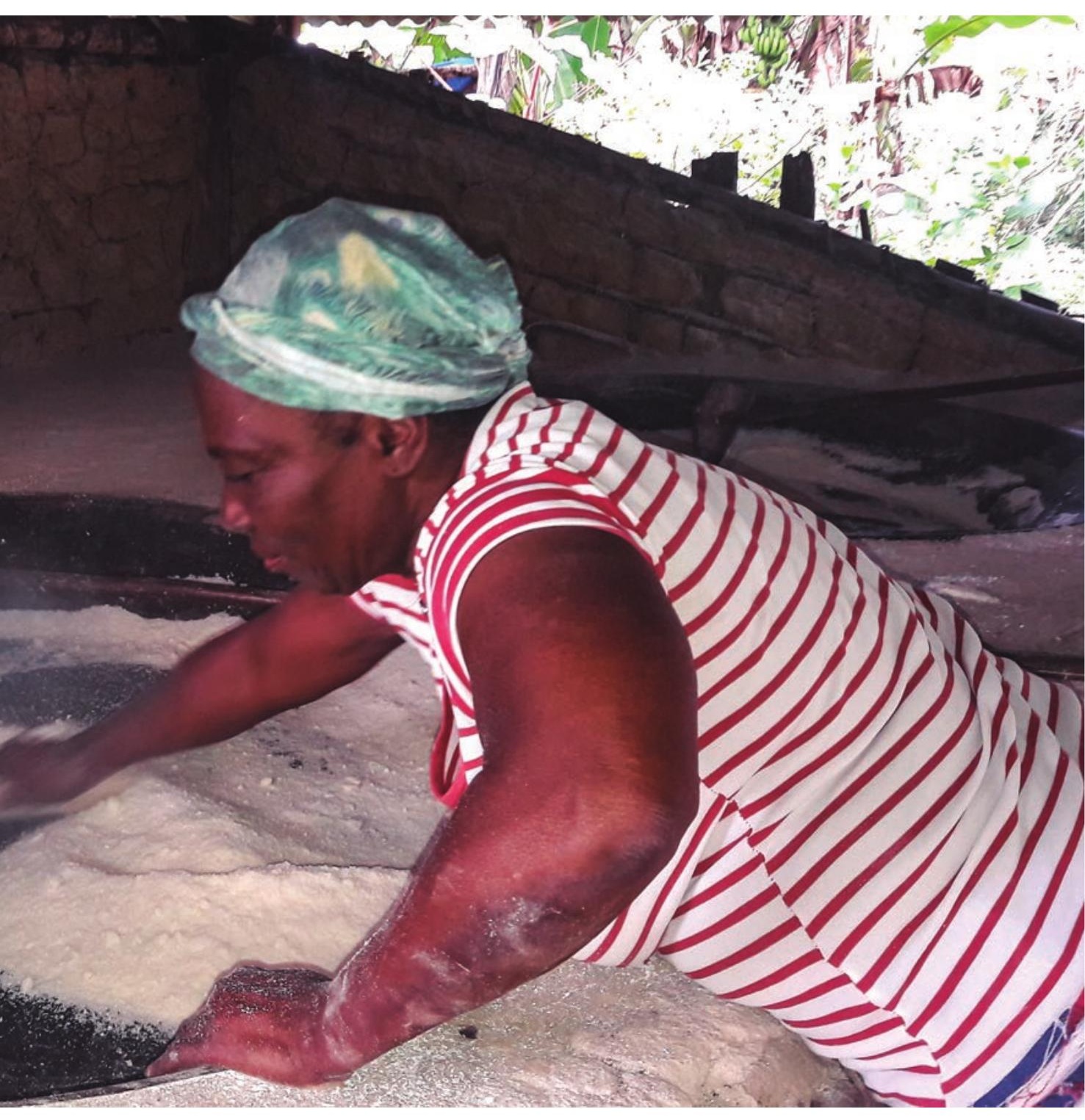




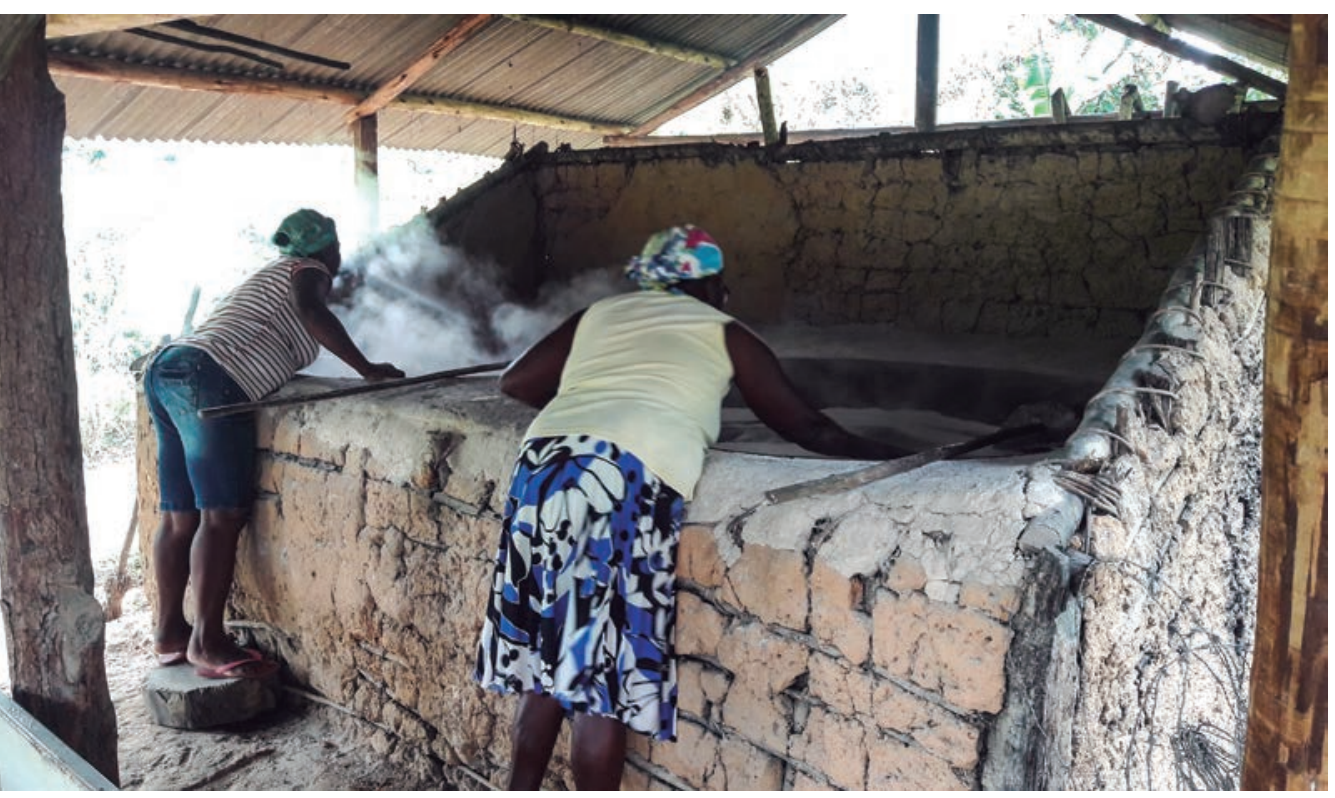




\subsection{DOMINGO ANTÔNIO}

Tudo nasce da terra... Bom, nem tudo. Há coisas que nascem do céu, e, "se vêm do céu, vêm diretamente de Deus". A interpretação do artista sobre a matéria prima da sua obra fala sobre orgulho e humildade.

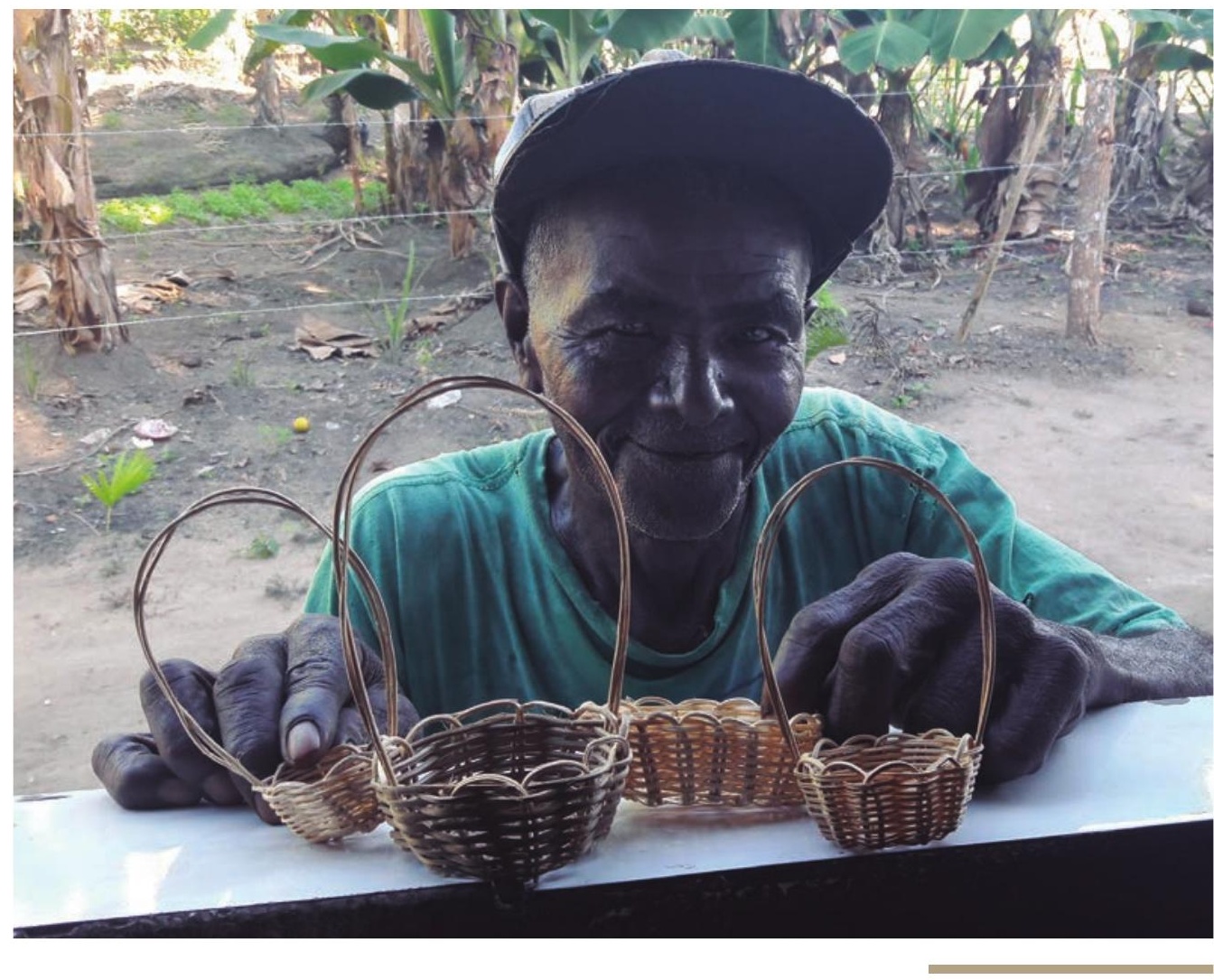

46 - Domingo

Antônio (2019). 
Ao se revelar parte de uma continuidade que vem desde os escravos, ele lamenta não ter guardado nenhum objeto do passado que mostre isso, mas se faz testemunha e prova viva de uma sabedoria e habilidade únicas, que vêm de muito longe... Ele se faz o homem forjado pelos homens e mulheres que vieram antes, muito antes dele.

Da mão à terra, desde o céu, Domingo Antônio tece afetividades com os fios da sua própria história.

"Eu vou lá pegá um pra sinhora ver". Domingo volta com pequenos e delicados cestos, tranças de palha que dão sustentação e forma às estruturas. "Essas são pequenininhas, tem muito maior", as menores demandam mais tempo de fabricação, pois as grandes exigem a mesma habilidade, mas ocupam menos tempo.

O artista faz lembrar que assim também são outras experiências da vida. A tecnologia chega, facilita a conversa com o mundo, mas é a conversa pequena, olho no olho, aquela que exige mais dedicação e entrega, a que revigora a humanidade e sensibilidade entre todos e fortalece a união.

Seu Domingo aprendeu a arte de trançar cipó com o seu pai, Antônio Manoel, que aprendeu com o seu pai (avô de Domingo), Manoel Eugênio. Os filhos de Domingo Antônio também aprenderam com ele a buscar o cipó na mata, cortar em filetes usando o ralo para que as tiras fiquem sempre do mesmo tamanho... e depois armar, a partir do mestre, o objeto que deseja, pequeno ou grande.

O artista faz carumbê ou samburá - para guardar alimentos -, lustres, cestos para guardar roupa, canambote, 
fruteira, cesta redonda com alça, faz panacum - cesto que era usado em cima do lombo de jegue ou burro para carregar mercadorias e/ou pessoas - e faz também vassouras de diferentes tipos. Desenhados a partir do mestre, os objetos ganham vida, e Domingo alerta: "se não tivé o mestre, nunca dá certo".

Esquecendo-se da grandiosidade da sua obra, o artista se maravilha: "Como é que pode né... Todas coisa que nasce é da terra, e esse camarada aqui [o cipó] é de cima". É realmente incrível... moldar o cipó que vem do céu à mão, ser artista e homem do campo, ser Domingo Antônio e ainda em prece admirar a divina grandiosidade da natureza.

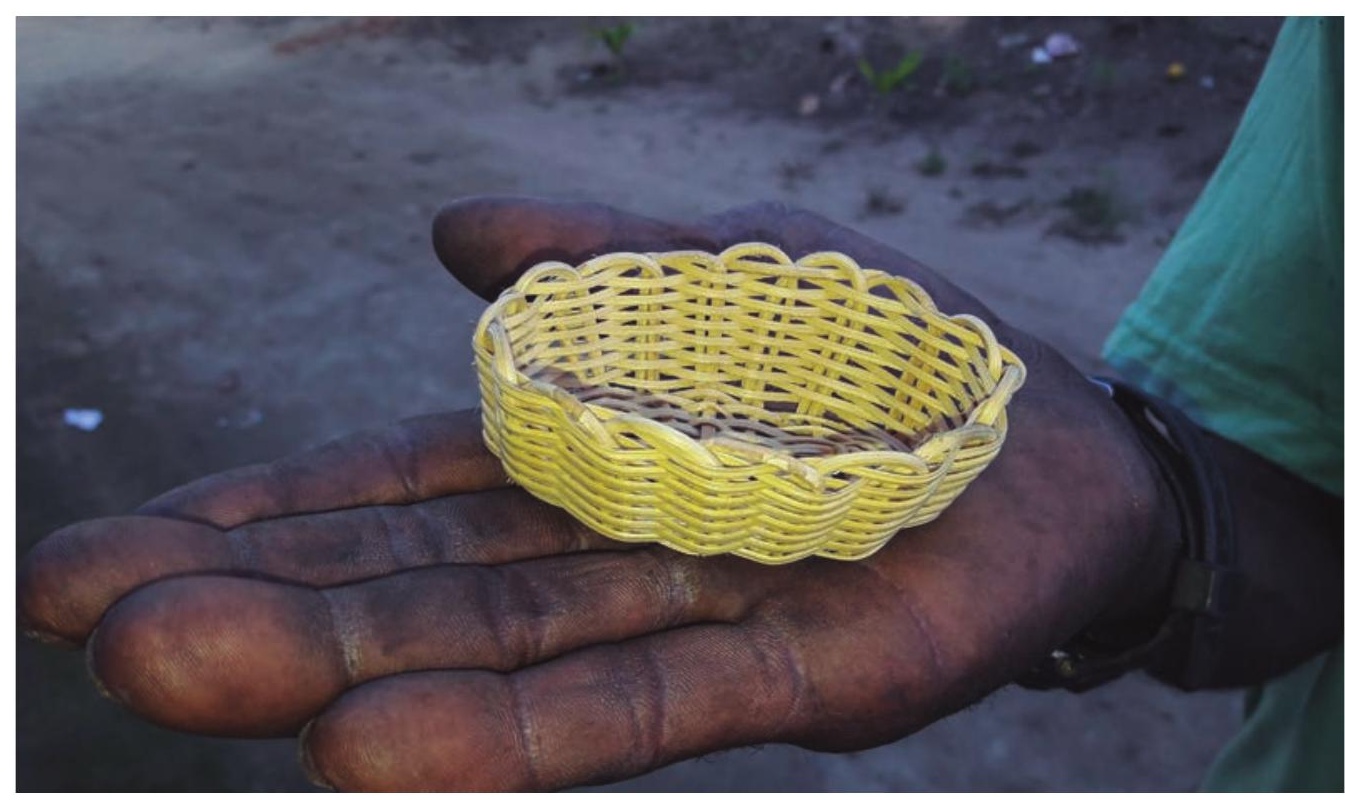




\subsection{MARIA DOS REIS}

Dona Maria apresenta os filhos, genro e os netos... sua história se confunde com a maternidade, de quem a gerou e dos que vieram a partir dela. "Criá filho hoje em dia é uma tarefa difícil, antes também era"... Mas por motivos diferentes.

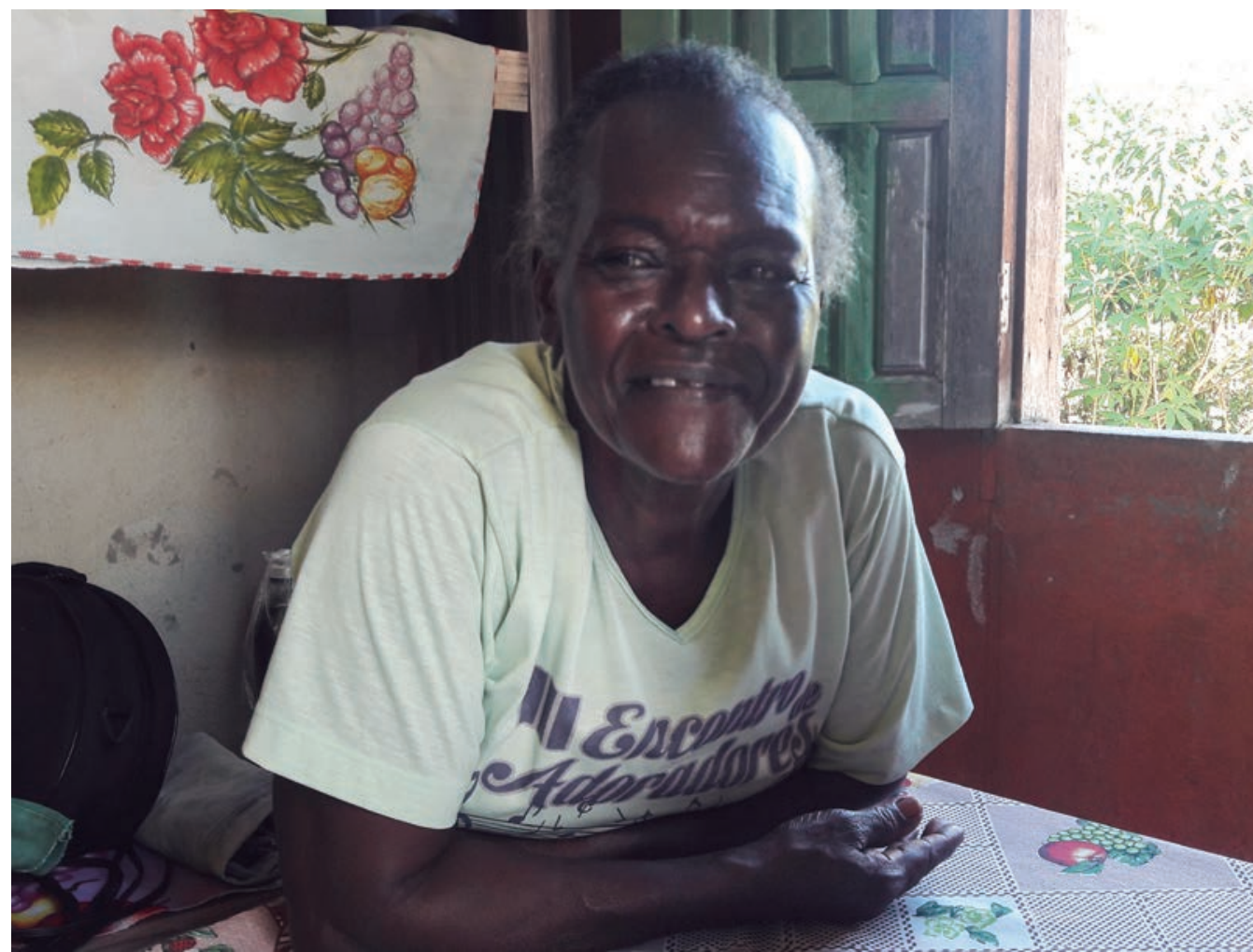


Os modos de viver do passado e do presente têm suas diferenças, mas Dona Maria segue construindo sua família como aprendeu. E segue aprendendo sempre.

O sustento vinha direto da mata, "não tinha emprego, mas ia no rio e pegava peixe desse tamanho, meu pai fazia armadia na mata e pegava caça, trazia para casa, limpava e passava sal, porque não tinha geladeira" - não tinha geladeira, mas também não havia fome.

Dona Maria aprendeu a conservar os alimentos com sal, sol, barro e brasa. A carne era salgada e seca ao sol, o feijão durava de um ano a outro: "misturava no barro, botava para secá e guardava" no carumbê, cesto trançado de cipó.

"Tudo mantinha a gente", o alimento vinha da mata e brotava da terra, que dava de tudo e eram alimentos saudáveis. Hoje os tempos são diferentes, mas Dona Maria dos Reis não fica parada, se não dá para ser como antes, ela vai à escola participar da reunião com pais e mestres, não perde uma reunião da associação, "porque assim a gente aprende e vai sabeno o que tá aconteceno, né". Dona Maria segue a vida como aprendeu a aprender: ouvindo atentamente, e assim ela vai cuidando dos seus. 


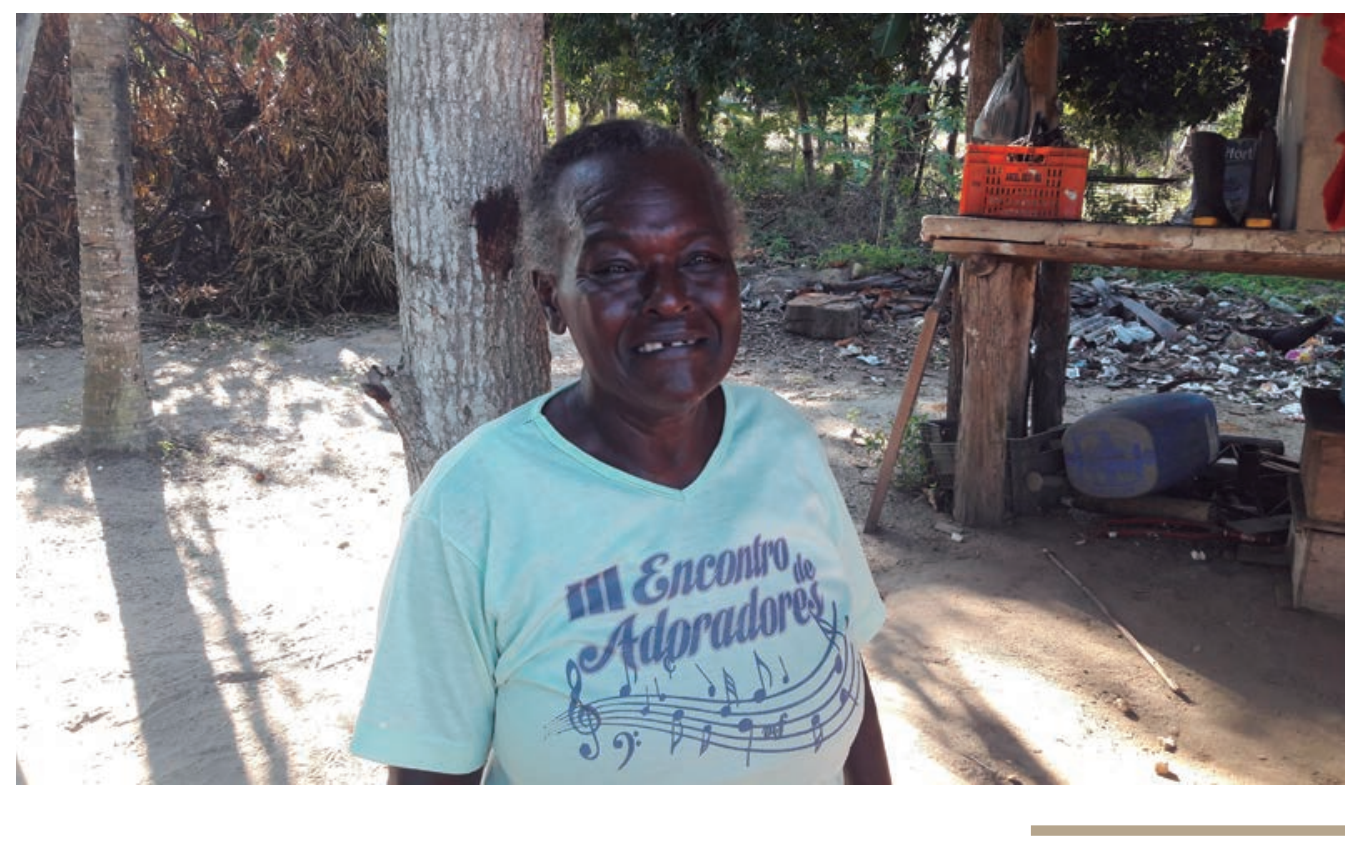

50 e 51 - Maria dos

Reis (2019). 


\subsection{NIDA}

A água para o café esquentava no fogão à lenha, junto a outras panelas. Num fim de tarde em que o sol se punha com preguiça, como quem precisa ir, mas tanto quer permanecer... talvez pela gentileza, afeto e saudosismo que se misturavam no ar. Dona Nida se levanta - apesar das dificuldades que os 82 anos the impõem, mesmo mantendo-Ihe ares de 60.

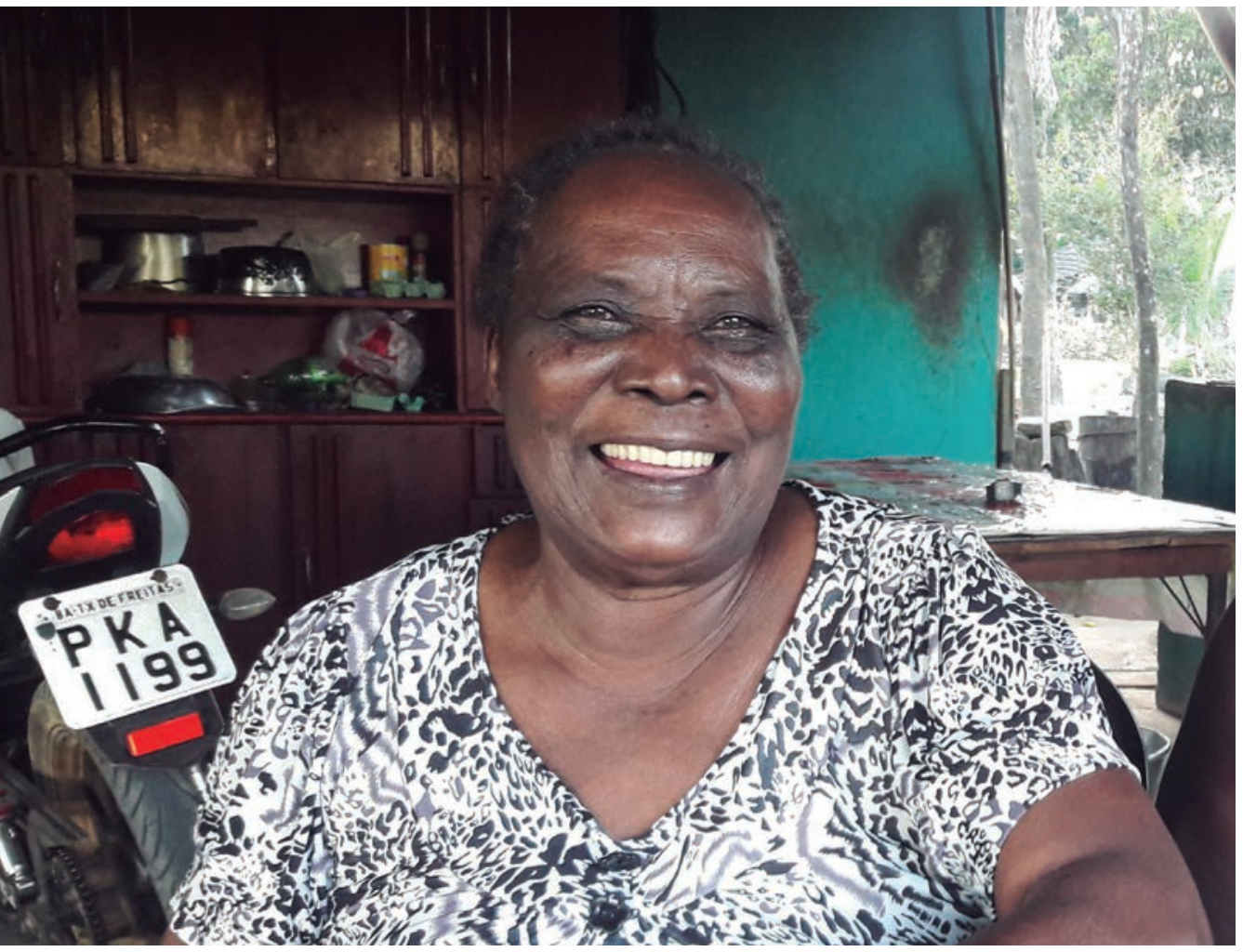

52 - Nida 
No meio da conversa, que se passava numa mesa posta à varanda, foi buscar a água de coco que, noutra oportunidade, Joaquim Serafim, seu marido, havia prometido... a conversa sobre a vida é tecida com pausas e silêncios, mas o sorriso de Dona Nida se abre sempre e ligeiramente, transformando a feição de quem, como ela mesma afirma, "já feiz muito na vida".

Os tempos de hoje podem até não ser bons... Mas Dona Nida garante que já fez "de um tudo, desde menina"... E eis que surge um motivo para sorrir.

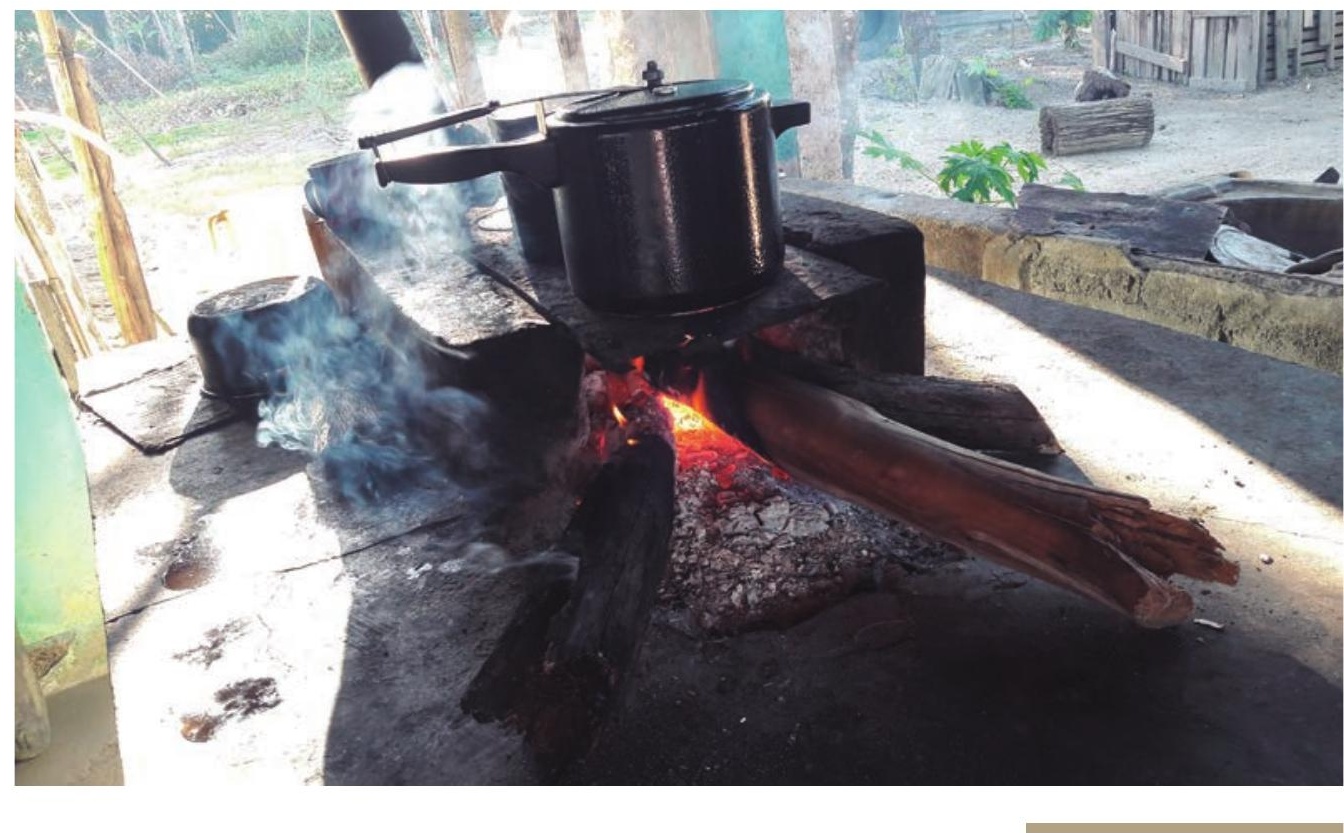

53 - Fogão à Lenha 


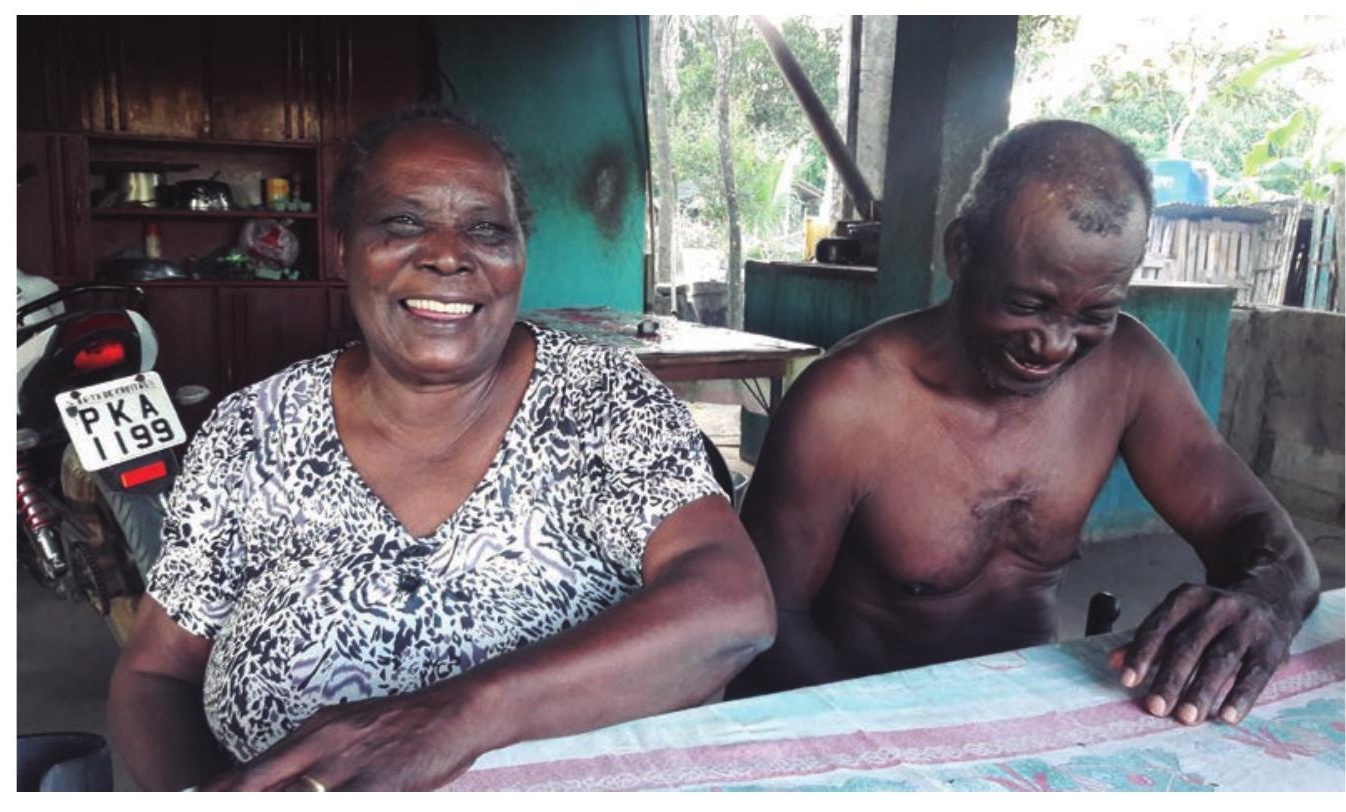

Ela sorri sobre um tempo em que havia muitas festas, 54 e 55 - Nida e Joaquim (2019). festas de santo. Vinha gente de toda a região... Helvécia, Juerana... e se ajuntavam numa casa, rezavam e festejavam - sambavam a liberdade e a fé - por toda a noite, desde o entardecer.

Dona Nida recolhe o sorriso: "A metade já acabô", o tempo passou, os foliões envelheceram... e o tempo deles chegou. A reza pelos mortos ainda continua, "reza no dia que morre, trinta dias reza, seis meis e ano". O sorriso se recolhe, há muito sentimento pelos que se foram e pelo samba que iluminava - que continua a iluminar, em memória, a sua face.

As falas de Dona Nida ecoam em Joaquim, seu marido. Os dois nascidos e criados em Volta Miúda foram se apaixonando com o samba. O encantamento presente no relato desse encontro faz surgir novos sorrisos - nos dois, 
ladeados. É ele que conta: durante o samba, garotas e rapazes trocavam olhares, iam conversando com os olhos, e se aproximando aos pouquinhos. E, de samba em samba, lá se vai meio século juntos.

Foi ele, limpando a roça, à beira da estrada, que convidou para conhecer a sua esposa. Parou a lida, ofereceu um café e uma prosa, apresentou Dona Nida, que fala em saudades que são um presente no presente... que são capazes de fazer brotar e resplandecer, novamente e sempre, um sorriso. São memórias que iluminam. 